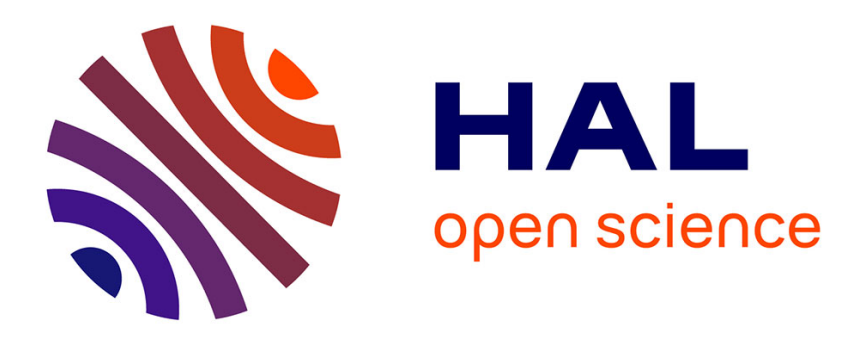

\title{
Why particles are not particular: Sentence-final particles in Chinese as heads of a split CP \\ Waltraud Paul
}

\section{To cite this version:}

Waltraud Paul. Why particles are not particular: Sentence-final particles in Chinese as heads of a split CP. Studia Linguistica, 2014, The Syntax of Particles, 68 (1), pp.77-115. 10.1111/stul.12020 . halshs-01574249

\author{
HAL Id: halshs-01574249 \\ https://shs.hal.science/halshs-01574249
}

Submitted on 17 Aug 2017

HAL is a multi-disciplinary open access archive for the deposit and dissemination of scientific research documents, whether they are published or not. The documents may come from teaching and research institutions in France or abroad, or from public or private research centers.
L'archive ouverte pluridisciplinaire HAL, est destinée au dépôt et à la diffusion de documents scientifiques de niveau recherche, publiés ou non, émanant des établissements d'enseignement et de recherche français ou étrangers, des laboratoires publics ou privés. 


\section{Why particles are not particular: Sentence-final particles in Chinese as heads of a split $\mathbf{C P}^{*}$ Waltraud Paul}

\section{Abstract}

Biberauer, Newton \& Sheehan (2009) claim that clause-final particles are categorially deficient. This move is motivated by the fact that a number of VO languages - among them Mandarin Chinese - display sentence-final particles (SFPs), which, when analysed as complementisers, violate the purportedly universal Final-over-Final Constraint (FOFC). The FOFC excludes structures where a head-final projection dominates a head-initial one. In contrast, the present article argues that SFPs in Chinese instantiate $\mathrm{C}$ in a three-layered split CP à la Rizzi $(1997,2004)$ and hence are "visible" for the FOFC. Furthermore, to equate The World Atlas of Language Structures' (WALS) label adverbial subordinator with complementiser as Biberauer et al. $(2008,2009)$ do is shown to be problematic, given that it turns out to be a cover term for different categories. Accordingly, WALS' results for the distribution of adverbial subordinator cannot be mechanically used as testing ground for the predictions made by the FOFC for the category $\mathrm{C}$.

\section{Introduction}

Biberauer, Newton \& Sheehan et al. (2009) claim that sentence-final particles (SFPs) are categorially deficient. The motivation for this claim is that SFPs seem to be the major, if not the only source of exceptions to the Final-over-Final Constraint (FOFC) prohibiting the combination of SFP with VO order. If accordingly SFPs are excluded, the data from The World Atlas of Language Structures (WALS; cf. Haspelmath, Dryer, Gil \& Comrie 2008) for the distribution of "adverbial subordinators" neatly patterns with the FOFC, because, with the exception of three cases, no VO language shows an "adverbial subordinator" in sentence-final position. The fact that Greenberg (1963) did not include particles in his typological studies, either, is adduced as an additional argument in favour of this approach (cf. Biberauer et al. 2009:712).

This approach, however, is not without problems. First, it is generally understood that particle is just a cover term resorted to precisely when no satisfying analysis of a particular item can be provided. This was probably the reason why Greenberg (1963) excluded them, the more so as the concept of 'functional category' was only introduced much later; not being able to assign a categorial identity to the items called particles made it impossible for him to take them into account for his word-order typology.

Second, to use data and figures from $W A L S$ as evidence for the FOFC is anything but straightforward. In particular, the reinterpretation of $W A L S$ ' term adverbial subordinator as 'complementiser' by Biberauer et al. (2009) is not self-evident at all. For adverbial subordinator clearly encompasses more categories than just C. This will be illustrated for Chinese where potential candidates for "adverbial subordinator" also instantiate the category of sentence-level adverbs, i.e. non-heads (cf. section 5 below).

Furthermore, equating adverbial subordinator with $\mathrm{C}$ amounts to excluding $\mathrm{C}$ in nonembedded contexts. In the light of the prolific research on the split root CP inspired by Rizzi

\footnotetext{
* This article has its origin in my talk given at the Workshop on Particles held at the University of Cambridge in October 2008. I thank the workshop organizers, Theresa Biberauer and Glenda Newton, for their kind invitation and the audience for feedback. I am also grateful to Thomas Lee, Victor Junnan Pan, Yang Zhitang Drocourt, and John Whitman for discussion and data. The comments of two anonymous reviewers are likewise acknowledged.
} 
(1997), this is an odd move, because it dismisses as irrelevant the studies covering a large number of typologically different languages over the last two decades (see inter alia Aboh 2006, Munaro \& Poletto 2006, Endo 2007, Haegeman this volume). With respect to a language such as Chinese, where complementisers are in general restricted to root contexts (cf. Paul 2009), the exclusive focus on embedding Cs leads to ignoring it completely. This is, however, highly unsatisfactory given that the traditional division of SFPs into three distributional classes (cf. among others Chao Yuen Ren 1968, chapter 8.5, Zhu Dexi 1982, Hu Mingyang 1981) displaying a rigid relative order can be successfully recast as a split CP à la Rizzi (1997) (cf. Paul 2005, 2009), modulo some changes to be discussed below:

$$
\text { Attitude }>\text { Force }>\mathrm{C}(\text { low })>\mathrm{TP}^{1}
$$

Importantly, this three-layered CP has existed since the 6th century B.C. (cf. Djamouri, Meisterernst \& Paul 2009), against the background of constant SVO order attested since the earliest documents dating from the 13th century B.C. (Djamouri 1988, Djamouri, Paul \& Whitman 2008, 2013a). Consequently, Chinese has been violating the FOFC for most of its history, displaying - at least at the surface - a head-final CP dominating a head-initial (TP and) VP.

My main purpose here is to argue in favour of SFPs as complementisers and against their being dismissed as "categorially deficient" in the sense of Biberauer et al. (2009), i.e. as items neither associated with $[ \pm \mathrm{V}]$ nor with $[ \pm \mathrm{N}]$. This also requires a comparison of SFPs with the Chinese equivalents of conjunctions such as because, if, although, etc. whose status is still under debate.

What I hope to convince the reader of is that SFPs are full-fledged functional elements of the category $\mathrm{C}$ and, as such, part of the grammar. Accordingly, they have to be taken into account by a constraint such as the FOFC and cannot be treated as quantité négligeable, somehow falling beyond its scope.

The article is organized as follows. Section 2 subjects the conclusions that can be drawn from the data in WALS and Dryer $(1992,2009)$ to a brief scrutiny. Section 3 argues in favour of the $\mathrm{C}$ status of the SFPs in Chinese and gives a short overview of the three classes of root complementisers implementing the subprojections Low CP, ForceP and AttitudeP in the split CP represented in Table 1. Section 4 provides evidence for the root vs. non-root asymmetry at work in the Chinese C-system and introduces the so far neglected non-root Cs de and dehua. Section 5 briefly discusses the equivalents in Chinese of English subordinating conjunctions such although, because, if, etc. and demonstrates that they do not form a homogeneous group, but must be further subdivided into sentence-level adverbs, on the one hand, and prepositions with clausal complements, on the other.

\section{The World Atlas of Language Structures and Dryer (1992, 2009)}

\subsection{The World Atlas of Language Structures (WALS)}

The data from WALS are presented as the crucial empirical basis supporting the FOFC prediction that VO languages lack sentence-final subordinating conjunctions, the sheer number of the languages included in the $W A L S$ database, i.e. - 2650 - seemingly vouching for

\footnotetext{
${ }^{1}$ Note that (1) abstracts away from linear order.
} 
the solidity of this claim. Accordingly, a careful study of Feature 94 "Order of adverbial subordinator and clause" is called for. ${ }^{2}$

According to Dryer (2008b), adverbial subordinators that are separate words correspond to the 'subordinating conjunctions' of traditional grammar and are exemplified by items such because, although, when, while, if in English. Dryer (2008b:10) also mentions the case where these adverbial subordinators "are formally adpositions combining with nominalized forms of verbs". This is the case for the preposition kárri in Krongo (Kugali, Sudan) expressing the meaning 'behind' when in combination with a (genitive) NP, and 'after' when occurring with the nominalized form of a verb in the genitive case (e.g. 'after drinking tea'). Among the clause-internal adverbial subordinators, one also finds enclitics attached to the first constituent in the subordinate clause as in the Australian language Yukulta (Tangkic, Queensland). Concerning cases of suffixal adverbial subordinators, Dryer includes case suffixes here, such as the instrumental -inda combining with gerunds to form 'because' clauses in Kannada (Dravidian, India). ${ }^{3}$

This is quite a heterogeneous group. It is true, though, that in the table combining word-order types with the (clause-initial, -medial, or -final) position of the adverbial subordinator, subordinators with word status are distinguished from those with suffix status. ${ }^{4}$ No distinction 'word vs. suffix', however, is made for the mixed order type.

Let us assume then - for the sake of the argument - that only adverbial subordinators with word status are considered to be complementisers by Biberauer et al. (2009), at least in those cases where the word status is explicitly mentioned. ${ }^{5}$ For VO languages, we obtain 279 cases of initial subordinator, and only 2 with final subordinator (Buduma and Guajajara). Note, however, the $30 \mathrm{VO}$ languages displaying mixed order for their subordinator where it is impossible to know whether the subordinator is a word or an affix. Interestingly, Cantonese figures among the (S)VO languages with mixed order, while Mandarin Chinese is not included in the sample of languages examined for Feature $94 .^{6}$

\subsection{Dryer $(1992,2009)$ on the distribution of $C$}

Since WALS does not have a feature examining the category 'complementiser' as such, let us turn to Dryer $(1992,2009)$ where the correlation between word order and the position of C is addressed explictly. Referring to his own work (Dryer 1980) as well as Hawkins (1990:225), Dryer (1992:102) concludes that "[...] in fact it may be an exceptionless universal that final complementizers are found only in OV languages. [...] complementizers are therefore verb

\footnotetext{
${ }^{2}$ Upon examination, the number of languages examined for Feature 94 turns out to be 611 , still impressive enough, but only a fourth of the total number of languages (i.e. 2650) included in the WALS database. It is thus not correct to state - as an anonymous reviewer does - that the lack of sentence-final subordinating conjunctions in VO languages has been confirmed for as many as 2650 languages. Whether in the light of this somewhat reduced number the correlation still counts as a quasi-incontestable robust empirical fact (as claimed by the same reviewer) remains for the reader to decide.
3 (i) Kannada (Sridhar 1990:74) (example 12 of Feature 94 by Dryer in $W A L S$ )

Bisilu hecca:giruvudar-

heat much ADV be N.PST GERUND.OBL-INSTR

'since it's very hot'

${ }^{4}$ Only subordinating suffixes are mentioned, to the exclusion of other affixal forms.

5 Note that Biberauer et al. (2009) do not mention the further distinction made within that group by Kayne (1991) between conjunctions instantiating C such as if, that and conjunctions analysed as NPs located in Spec, CP such as whether and when.

${ }^{6}$ This contrasts with Dryer's (2008b:12) statement that “Clause-final subordinators that are separate words are common in (i) an area in Asia stretching from India northeast through Myanmar and China into northeastern Asia [...]." (emphasis mine).
} 
patterners, while the Ss they combine with are object patterners." This is confirmed by Dryer (2009) where explicit reference is made to English that as illustrating a clause-initial C and to Japanese to as illustrating a clause-final C, respectively. ${ }^{7}$ Unfortunately, Dryer (2009) only indicates language genera; accordingly, there is no way to know whether Mandarin Chinese or any other Sinitic language was among the 140 VO languages included in the survey and which all show a clause-initial C.

When examing polar question particles, Dryer (1992:103) draws an explicit parallel with English whether and discusses the possibility of analyzing polar question particles in peripheral (sentence-initial or sentence-final) position as complementizers. Here he likewise concludes on their status as verb patterners. Interestingly, Dryer's (1992) example from the Australian language Mokilese displays a root question with a sentence-initial question particle, i.e. the mirror image of Chinese where the question particle is at the end of the sentence. (Note that Dryer 1992 does not include Chinese in his database).

\subsection{The problem of descriptive adequacy in WALS}

As already noted, WALS also examines the position of polar question particles (cf. Feature 92). When correlating it with word order, SOV and SVO languages in fact behave more or less alike, insofar as for both word orders, the sentence-initial position is much rarer (24 and 40 languages, respectively) than the sentence-final position (106 and 110, respectively). While this time Chinese is included among the languages with the question particle in sentence-final position, no analysis as $\mathrm{C}$ of polar question particles (when in peripheral position) is evoked anymore. On the contrary, an extremely well-studied and easily accessible language such as French sees itself classified among languages marking polar questions with sentence-initial "particles", like the Australian language Mokilese just mentioned or !Xóõ (Southern Khoisan, Bhotswana), and, hence, as the mirror image of Chinese. The "particle" alluded to is est-ce que (cf. Dryer 2008a), which Dryer (ibid.) at the same time acknowledges to have composite status ('verb plus demonstrative plus complementiser'). The particle analysis of est-ce que cannot be correct given the existence of the corresponding negated form 'n'est-ce pas que + sentence', which indicates that the copula in est-ce que is clearly identifiable as such. The sequence est-ce que can therefore not be analysed as a particle, i.e. as an $\mathrm{X}^{\circ}$ whose sub-components are opaque to syntactic operations. Furthermore, est-ce que also occurs in $w h$-questions and is then preceded by the $w h$-phrase, i.e., the alleged particle est-ce que is neither always sentence-initial nor does it exclusively serve to form yes/no questions. Accordingly, its description as a sentence-initial polar question particle appears patently inadequate. (For an in-depth discussion of est-ce que, cf. Munaro \& Pollock 2005.) The fact that such a misleading analysis is proposed for a well-known language such as French is quite disturbing and casts doubt on the appropriateness of analyses in the case of languages where only second-hand knowledge via consulting grammars is available. This is evidently the case for the majority of languages: WALS is dependent on the adequacy and exhaustiveness of the grammars used and must fail where the respective grammars fail.

This caveat might at first sight seem trivial and is readily acknowledged by everyone working with results from $W A L S$, notwithstanding a certain schizophrenia observed when a generalization finds itself confirmed by the majority of languages in WALS's database; in such a case the temptation to dismiss counterexamples as irrelevant in the face of the statistical predominance often is just too strong. However, the role played by $W A L S$ as an

\footnotetext{
${ }^{7}$ Dryer (1992) does not provide any example of what he refers to as $C$. He contents himself with the following statement: "I will not cite data on the order of complementizer and S of the sort presented for other pairs of elements in this paper, but there seems to be little question that this is a correlation pair." (Dryer 1992:101.
} 
implicit typological standard of comparison influencing language-specific analyses is neglected, although it leads to a considerable bias in language descriptions. Let us again illustrate this with reference to Chinese, which is said to only have prepositions, and no postpositions (cf. WALS Feature 85). ${ }^{8}$ At first sight, this seems plausible enough because it accords with our "expectations" that VO languages have prepositions, but no postpositions. However, this claim is straightforwardly invalidated by Ernst (1988), who has clearly established the postpositional status of at least three items in their use as spatial locatives, i.e. shang 'on', xia 'below', and $l i$ 'in' (For further evidence in favour of the existence of postpositions in Chinese along with prepositions, cf. Djamouri, Paul \& Whitman 2009, 2013b). The fact that Ernst's work was not taken up by further studies and as a result was not included in the description of Chinese by $W A L S$ in turn then serves as confirming evidence for those reluctant to admit the existence of pre- and postpositions, a situation conceived of as a typological "oddity", albeit attested for other languages, e.g. German (which according to WALS, though, has prepositions only). ${ }^{9}$

To summarize, the language descriptions in WALS do not constitute "raw" data and consequently cannot be taken at face value: they have gone through a filter consisting of our preconceived - and, for that matter, not always correct - ideas regarding what pattern combinations to expect in languages, This "filter" either finds itself already incorporated into the analysis proposed by the specialist of the language at hand or is imposed subsequently by the way the language-specific analysis is processed in $W A L S$.

\section{The internal architecture of the split $\mathrm{CP}$ in Chinese}

Traditionally, Chinese linguists (cf. among others Zhu Dexi 1982, chapter 16) identify three distributional classes of SFPs, whose relative order is fixed: [[[TP $\left.\left.\left.C_{1}\right] \mathrm{C}_{2}\right] \mathrm{C}_{3}\right]$. These three classes can be recast as a split CP in the spirit of Rizzi (1997), as reflected in the labels assigned to each class in Table 1. Note that the SFPs within a given class are mutually exclusive.

\footnotetext{
${ }^{8}$ When recently consulting http://wals.info (March 19, 2013), this had been corrected. Feature 85A concerning the order of adposition and noun phrase now states the lack of a dominant order for Mandarin, hence the existence of both prepositions and postpositions.

${ }^{9}$ It is the concept of cross-categorial harmony (cf. Hawkins 1983) that assigns languages with both pre- and postpositions a "marked", "exceptional" status. For in such a case, one type of adposition will be "disharmonic" with the main word order. In the case of Chinese, only prepositions are expected, because this reflects the same head-complement order as that displayed by verb and object. Ernst (1988:231) himself discusses the tension between his own result of postulating postpositions and the predictions made by a parametric word-order theory for a VO language such as Chinese, the same direction of Case assignment being expected for verbs and adpositions. This tension can be solved within the radically different view of the concept of cross-categorial harmony provided by Whitman (2008). Whitman (2008) argues in detail that cross-categorial generalizations are the result of well-documented patterns of language change, hence statistical in nature, but not part of UG. Exceptions to "harmonic" situations are therefore precisely what we expect; they arise when the historical origin of an item is different from the one observed in the languages having served as the basis for the generalization. Adpositions are a case in point; if they result from the reanalysis of $\mathrm{V}$, as in the case of Chinese prepositions, they pattern with $\mathrm{V}$, contrary to adpositions with a non-verbal origin, which is the case for the Chinese postpositions. Note that in the new perspective provided by Whitman (2008), the statistical pre-dominance of certain correlations (e.g. VO and head-initial $\mathrm{CP}$ ) is basically a matter of contingency and can therefore not be adduced as evidence for constraints of a grammatical nature such as FOFC.
} 
Table 1 The three classes of root complementisers

\begin{tabular}{|c|c|c|}
\hline (low C) $\mathrm{C}_{1}$ & $\mathrm{C}_{2}$ (force) & $\mathrm{C}_{3}$ (attitude) \\
\hline le currently relevant state & $m a$ interrogative & ou warning \\
\hline láizhe recent past & $b a$ imperative & $(y) a$ astonishment \\
\hline$n e_{1}$ continued state & $n e_{2}$ follow-up question & $n e_{3}$ exaggeration \\
& $\ldots \ldots \ldots$ & $\ldots \ldots .$. \\
\hline
\end{tabular}

In order to provide evidence for the C-status of SFPs, a brief overview of the syntax and semantics of SFPs is necessary. This overview can only give a general idea of the complementisers and their hierarchy in Chinese and is by no means meant to be exhaustive nor to render the exact semantic import of each SFP. While the semantic import is the clearest in the case of SFPs instantiationg Force, it is much less straightforward to determine for the two other classes. Evidently, this only illustrates the inadequacy of our comprehension of the SFPs and does in no way entail that the $C_{1}$ and $C_{3}$ classes are intrinsically "vague" or exclusively context-dependent. In reality, the meaning of the SFP itself, the propositional content, the intonational contour and the extralinguistic context interact in a complex way which still needs to be analysed. ${ }^{10}$ (For a descriptive overview of SFPs, cf. among others Chao Yuen Ren 1986, chapter 5; Li \& Thompson 1981, chapter 7.)

Before starting the discussion of SFPs as such, some preliminary remarks concerning the phrase structure of Chinese are called for. Huang C.-T. James (1982, chapter 2) demonstrated in detail that IP as well as the lexical categories are head-initial (with the exception of the head-final NP), resulting in a uniformly right-branching structure for the IP/TP. Accordingly, any element after the object(s) of the verb must occupy a position outside the $v \mathrm{P}$ and, by extension, outside the IP/TP (given that the projections above $v \mathrm{P}$ up to TP such as AspP and AuxP are also head-initial). ${ }^{11}$ This is precisely the case for SFPs. In fact, their position outside the (core) sentence has long been known in the Chinese literature, where they have always been described as relating to the entire sentence. Accordingly, SFPs are formally equivalent qua their being located in (the different subprojections of) the sentence periphery, above TP. With respect to their semantic import, however, they are not homogeneous at all, as can be easily deduced from the descriptions of the SFPs figuring in Table 1 and from the discussion in the remainder of this section.

The analysis of SFPs as complementisers goes back to Lee Hun-tak Thomas (1986), who was the first to claim C-status for the yes/no question particle $m a$. The analysis of $m a$ as $\mathrm{C}$ has become standard since and has been substantiated by subsequent studies (cf. inter alia Tang Ting-chi 1989, Cheng Lisa Lai-Shen 1991, Li Yen-Hui Audrey 1992). My proposal is to extend this analysis in terms of $\mathrm{C}$ to all SFPs in Mandarin, drawing on research within the split CP approach of Rizzi (also cf. Li Boya 2006, Hsieh \& Sybesma 2008 for Mandarin, and Sybesma \& Li Boya 2007 for Cantonese). ${ }^{12}$ We will see that SFPs are not categorially

\footnotetext{
${ }^{10}$ In the vast Chinese descriptive literature on SFPs, more recent case studies of individual SFPs start taking into account this complex interaction and include, for example, the role of sentence intonation. Consider, among others, Jiang (2008).

${ }^{11}$ This is somewhat simplified insofar as a (secondary) predication on the matrix object occupies a $v \mathrm{P}$-internal position (cf. Huang C.-T. James 1984: 568ff; Paul 1988, chapter 7):

(i) Zhāngsān mǎi-le yī-dòng fángzi $i_{i}\left[\right.$ wŏ hěn xǐhuān $\left.\mathrm{e}_{\mathrm{i}}\right] \quad$ (= Huang's 1984: 569, (95))

Zhangsan buy-PERF 1-CL house 1SG very like

'Zhangsan bought a house, which I really like.'

Such an analysis is evidently excluded for SFP, confirming their position above TP. Note that SFP were not discussed in Huang C.-T. James (1982).

${ }^{12}$ Strangely enough, the yes/no question particle $m a$ is not considered as realizing the head Force by Li Boya (2006), although Rizzi's split CP approach serves as the basis of her dissertation. Quite on the contrary, Li Boya
} 
deficient, as claimed by Biberauer et al. (2009). Their view of SFP seems to be partly motivated by the lack of phonetic substance and the clitic nature of SFPs. However, similarly phonetically "weak" or "light" elements such as the article the in English are not analysed as acategorial elements (e.g. $\mathrm{D}^{\circ}$ ) for that reason. In Chinese grammar as well, quite a number of monosyllabic items have been accorded full-fledged categorial status "inspite" of their surface clitic properties - consider the aspectual suffix -le (cf. (5) below) which "leans on" to the verb and the general classifier ge which forms an intonational unit with the preceding numeral.

\subsection{Low C: le, laizhe, ne}

Let us start with the SFPs instantiating the lowest subprojection of $\mathrm{C}$ above TP. ${ }^{13}$

\subsubsection{Low Cle}

The semantic import of the low $\mathrm{C}$ le is difficult to determine and still the subject of ongoing research. ${ }^{14}$ There seems to exist no common denominator for all the different cases where $l e$ appears other than that it closes off the sentence and relates the event to the speech time. indicating that it obtains as a new situation (whence Li \& Thompson's 1981 description of le as signaling 'currently relevant state').

(2) [ [ ст [тр Wǒ zuótiān dào Zhāng jiā chī fàn ] le]

$1 \mathrm{SG}$ yesterday go Zhang home eat food clow

'I went to the Zhangs for dinner yesterday.'

(Chao Yuen Ren 1968:798)

Āiyā , [shíyī diăn bàn ] le!

oh 11 o'clock half clow

'Goodness, it's (as late as) half past eleven!'

(Chao Yuen Ren 1968:798)

$$
\begin{aligned}
& \text { [CPlow[Tорр[тр Wǒ ȳ̄ ān mén-líng] [Tор' [тP tā jiù lái kāi mén] le ]]] } \\
& \text { 1SG once ring door-bell 3SG then come open door clow }
\end{aligned}
$$

'As soon as I rang the door bell, he came and opened the door.'

(slightly modified example from Chao Yuen Ren 1968:799)

In (2), le signals that the proposition is presented by the speaker as her/his contribution relevant to the conversation at hand and can be paraphrased as 'here is what I have to say'. Example (3) illustrates that a situation can be new with respect to the subjective perception of

(2006) goes as far as claiming that the clause-typing heads, i.e. Force and Mood in her work, always remain covert in Mandarin and Cantonese (whereas they may be realized overtly in Wenzhou). Like other studies on the Chinese SFP subsequent to Lee Hun-tak Thomas (1986) and Tang Ting-chi (1989), she takes the C-status of SFP for granted and does not attempt to demonstrate it explicitly.

13 Given the differences between Rizzi's hierarchy and the one proposed here for Chinese, the lowest subprojection is not labeled Fin as in Rizzi (1997), but Clow (cf. Paul 2005 for further discussion).

${ }^{14}$ Li Yen-hui Audrey (1992:153, note 16) tentatively suggests Infl-status for the sentence-final particle le. Given its unacceptability in relative clauses (cf. (39a) below), this cannot be correct, though. The same caveat applies to Tang Sze-Wing (1998:39 ff) who locates the SFPs le and láizhe in T (and stipulates T-to-C movement in Chinese). Li Boya (2006:171) - without further explanation - analyses le as the category Deik. The only other passage discussing le is p.125, where it is likened to the SFP le in Cantonese "mark[ing] realization" and illustrated by example (i) (her glosses and translation):

(i) Wǒ xīn -lî biàn de gāoxìng hé qīngsōng de duō le

1SG heart-inside become DE happy and relieved DE much PRT

'My heart has become much happier and more relieved.' (= Li Boya's (3b), p.125) 
the speaker. (4) finally shows that when an explicit reference time is provided ('as soon as I rang the bell'), le relates the event to that time.

Even though the semantic contribution of le often remains elusive, its presence imposes grammatical constraints. As already observed by Teng Shou-hsin (1973:26), le interacts with material inside TP and in that respect is different from the SFP in the $\mathrm{C}_{2}$ and $\mathrm{C}_{3}$ positions. (This also holds for the low Cs laizhe and ne; cf. sections 3.1.2 and 3.1.3. below.)
a. $\quad[$ CPlow $[$ тр Tā chī-le fàn $]$ le $] .^{15}$ $3 \mathrm{SG}$ eat-PERF food clow
'He has eaten.'
b. $\quad *$ [CPlow [тр Tā méi chī fàn $]$ le $]$. 3SG NEG eat food clow 3SG NEG eat food
'He hasn't eaten.'
c. $\quad[$ CPlow $[$ TP Tā méi chī fàn $]]$.

$$
\begin{aligned}
& \text { [CPlow [TopP Nà [Top' [TP wǒ jiù bù děng tā ] le ]]]. } \\
& \text { in.that.case } 1 \text { SG then NEG wait 3SG Clow } \\
& \text { 'In that case I won't wait for him any longer.' }
\end{aligned}
$$

Let us first look at (6) with the "neutral" negation bù, compatible with stative and activity verbs (cf. inter alia Teng Shou-hsin 1973, Li \& Thompson 1981, Ernst 1995, Hsieh MiaoLing 2001, Lin Jo-wang 2003). The meaning of this sentence is derived in a straightforward compositional way which nicely reflects that $l e$ as $\mathrm{C}$ has scope over the entire sentence: le signaling that the proposition 'I won't wait for him' obtains at the speech time (in the absence of any other reference time), we obtain 'I won't wait for him any longer'. (5b), by contrast, is unacceptable because there is a contradiction between the negation of the completion of an event mediated by méi and the requirement of le to relate this state of affairs to the speech time and present it as a newly obtained situation (also cf. Sybesma 1999:64)

\subsubsection{Low C láizhe}

Láizhe usually indicates that the event time is recent past (7), but 'recent past' can also apply to the speech time of a preceding utterance or refer to a former state of knowledge as in (8b) (cf. Chao Yuen Ren 1968:810):

(7) [CP [TP Nà màozi zài nàr guà -zhe $]$ láizhe $]$, [CP [TP zěnme bù jiàn $]$ le $]$ ? that hat at there hang-DUR clow how NEG see clow

'The hat was hanging there. How come it's no longer here?'

(slightly modified example from Chao Yuen Ren 1968:810)

$$
\begin{aligned}
& \text { a. Ň̃ xìng shénme? } \\
& \text { 2SG call what }
\end{aligned}
$$

\footnotetext{
15 Note that the verbal suffix -le indicating perfective aspect is distinct from the homophonous SFP le, "although" both behave as clitics on the surface and form a phonetic unit with the preceding word (cf. Chao Yuen Ren 1968, Teng Shou-hsin 1973). Unlike the SFP le realizing C, the perfective -le instantiates the head $A s p^{\circ}$ situated above $v \mathrm{P}$ and attracting V (cf. Lin Tzong-Hong 2001; Paul \& Whitman 2010).
} 
'What's your family name?'

b. [СР [тр Nĩ xìng shénme] láizhe]? (Chao Yuen Ren 1968:810)

2SG call what Clow

'What (did you just say) is your family name?'

'What was your family name?' (I forgot.)

Like le, láizhe has access to material inside TP. It is incompatible with negation (both bù and méi), because, in addition to locating the event in the recent past, it also asserts its having taken place (cf. Song Yuzhu 1981:275, Lü Shuxiang et al. (eds.) 2000:348-349): ${ }^{16}$

(9) (a) Nǐ gāngcái shuō shénme láizhe ?

2SG just say what Clow

'What did you just say?'

(b) Wǒ méiyǒu shuō shénme (*láizhe).

1 SG NEG say what Clow

'I didn't say anything.'

Wǒ (*méi) qù Tiānjīn láizhe.

1SG NEG go Tianjin Clow

'I have (not) been to Tianjin.'

The event-assertion component of láizhe also accounts for the fact that only wh- questions are compatible with láizhe (cf. 9a), to the exclusion of yes/no questions formed by adding méi yŏu 'not have':

*Tā shuō huà méi yŏu láizhe ?
3SG speak word NEG have Clow
('Did he talk?')
(Lü Shuxiang et al. 2000:349)

Consequently, a yes/no question can only be followed by láizhe when an interpretation as a rhetorical question is possible, thus reinforcing the assertion. This is the case with shi bù shi 'is it the case or not' questions implying that the speaker presupposes a positive answer:

Zuótiān nĭ shì bù shì qù kàn xiāngshān láizhe? yesterday 2SG be NEG be go see Xiangshan Clow 'Didn't you go to see the Xiangshan yesterday?'

(Lü Shuxiang et al. 2000:349)

\subsubsection{Low $\mathrm{Cne}_{1}{ }^{17}$}

\footnotetext{
${ }^{16}$ Being realizations of the same C-subprojection, le and láizhe cannot co-occur in the same sentence (cf. (ii)):

(i) Ta shuō shénme le / láizhe? 3SG say what Clow/Clow 'What did he say?'

(ii) *Ta shuō shénme $\{$ le láizhe\} / \{ láizhe le \}? 3SG say what Clow Clow / Clow Clow
} 
The low $\mathrm{C} n e_{1}$ requires a TP complement containing a stative predicate (e.g. an adjective or a verb in the durative aspect):

$$
\begin{aligned}
& \text { [CPlow [TP Wàibiàn xià-zhe yǔ ] ne ]. } \\
& \text { outside fall-DUR rain Clow } \\
& \text { 'It is still raining outside.' }
\end{aligned}
$$

$$
\begin{gathered}
\text { [CPlow[тр Yǒu yībái chǐ ] ne ], [СР [тр shēn dehěn ] ne ]. } \\
\text { have } 100 \text { foot Clow deep extremely Clow }
\end{gathered}
$$

'It's as much as a hundred feet, it's quite deep.' (Chao Yuen Ren 1968:802)

To summarize, the low $\mathrm{C}$ heads le, laizhe and $n e_{1}$ have in common that they impose restrictions on their TP complement in terms of the properties of its extended VP. In other words, the low $\mathrm{C}$ heads in Chinese have as close a relationship with $\mathrm{T}$ as the $\mathrm{C}$ elements in Indo-European languages and must therefore access the features of the $\mathrm{T}$ head, instead of only looking at the TP label (contra Cecchetto 2013). ${ }^{18}$

\subsubsection{Some remarks on the feature make-up of $C$}

A brief digression into the feature make-up of $\mathrm{C}$, an issue so far not adressed in the Chinese literature, seems indicated here. ${ }^{19}$ The interaction of Clow with properties of the extended VP projection (aktionsart of the verb, presence/absence of negation, etc.) suggests that Clow bears a verbal feature. If this turns out to be correct, Clow needs to be taken into account by the FOFC because CP will then be categorially identical with TP (in terms of the features [+V], [ $\left.{ }_{-} \mathrm{N}\right]$ ) (cf. Biberauer, Holmberg \& Roberts 2007) and/or on the same projection line as TP (cf. Biberauer et al. 2009), these being the conditions imposed on heads/projections having to obey the FOFC. In other words, the FOFC allows a "nominal", but not a "verbal" headfinal CP to dominate a head-initial TP. While the precise feature make-up of the C elements must be strictly determined within the synchronic grammar of Mandarin, let us nevertheless venture into the origin of the low $\mathrm{C}$ heads, notwithstanding the well-known fact that this kind of knowledge cannot be part of the native speaker's linguistic competence. Le in general is linked etymologically to the verb lái 'come' (cf. Chao Yuen Ren 1968:246, footnote 31). Láizhe can probably be decomposed into the verb lái 'come' and the locative verb zháo 'adhere to, be in the proximity of' (Redouane Djamouri, p.c.); the origin of the SFP nevertheless remains unclear (cf. Chen Qianrui 2005). Note, however, that well-established etymologies such as le < lái 'come' are proposed for the items taken in isolation and completely abstract away from the syntactic position of the items under investigation. Accordingly, they are of limited interest only, because very probably the SFP was simply homophonous with the verb proposed as its "source" and therefore written in the same way.

\footnotetext{
${ }^{17}$ The low $\mathrm{C} n e$ is noted as $n e_{1}$ in order to distinguish it from the Force head $n e_{2}$ and the Attitude head $n e_{3}$ (cf. the three instances of $n e$ in Table 1 above).

${ }^{18}$ Cecchetto (2013) claims that Chinese $\mathrm{C}$ does not access the features of the $\mathrm{T}$ head, unlike $\mathrm{C}$ in Indo-European languages. He postulates this difference concerning the relationship of $\mathrm{C}$ with $\mathrm{T}$ precisely in order to account for the FOFC violating configuration present in Chinese, where a head-final CP dominates a head-intial TP.

${ }^{19}$ Biberauer, Holmberg \& Roberts. (2008) attribute to Li Boya (2006) the view that C in Chinese is nominal. However, my own reading as well as an electronic search of her thesis produced no result for such a statement. To my knowledge, the question of the feature make-up of $\mathrm{C}$ has so far not been addressed in Chinese linguistics, and at this point is certainly not backed up by any independent evidence going beyond the general parallel postulated between $\mathrm{CP}$ and the nominal domain.
} 
(For a diachronic approach which does take into account the syntactic structures involved, cf. Aldridge 2011.) Finally, as is to be expected, some SFPs are first attested as such, i.e. as SFPs, although with a different pronunciation due to subsequent sound changes. This is the case for $n e: n e<n i<l i$ (cf. Pan 2007:81ff). ${ }^{20}$

\section{2. $C_{2}$ heads expressing the sentence type (Force): $m a, n e_{2}, b a$}

As already mentioned above, the SFP $m a$ indicating the yes/no question status of a sentence (cf. (15b)) was the first SFP to be analysed as C (cf. Lee Hun-tak Thomas 1986, Tang Tingchi 1989):

a. Tā huì shuō zhōngwén.

3SG can speak Chinese

'He can speak Chinese.'

b. [CPforce [тP Tā huì shuō zhōngwén] ma ]?

3SG can speak Chinese FORCE

'Can he speak Chinese?'

Since ma turns a (declarative) sentence into a yes/no question, it must have scope over the entire sentence, whence the analysis of $m a$ as a C-head taking a TP complement. The complement status of TP and the head status of $m a$ are confirmed by the fact that $m a$ imposes selectional restrictions: it can only select a non-interrogative TP and is therefore incompatible with TP-internal yes/no questions in the 'A-not-A' form and $w h$-questions (for 'A-not-A' questions, cf. Huang C. -T. James 1982):

$$
\begin{aligned}
& \text { a. } \quad\left[\text { CPforce }[\mathrm{TP} \text { Nĩ wèn-le shéi }]\left(*^{\mathrm{ma}}\right)\right] ? \\
& 2 \mathrm{SG} \text { ask -PERF who FORCE } \\
& \text { 'Whom did you ask?' }
\end{aligned}
$$

b. [CPforce [TP Shéi wèn-le nĭ $](*$ ma $)]$ ? who ask -PERF 2SG FORCE

'Who asked you?'

$$
\begin{aligned}
& \text { [CPforce [тр Tā dŏng bù dŏng wèntí ] (*ma)] ? } \\
& \text { 3SG understand NEG understand problem FORCE } \\
& \text { 'Does he understand the problem?' }
\end{aligned}
$$

As for the SFP $n e_{2}$, it is familiar to scholars in general linguistics because it has been claimed to play a crucial role in typing a sentence as question in $w h$ in-situ languages such as Chinese (cf. Cheng Lisa Lai-Shen 1991). This is, however, invalidated by the well-known

\footnotetext{
${ }^{20}$ The "source" itself might also present a dilemma with respect to its verbal or nominal nature, as in the case of SFPs in the Italian dialects Pagotto and Veneto from the North-Eastern area, examined by Munaro \& Poletto (2006). They retrace personal pronouns as the source for the SFPs $t i$ and $l u$, but temporal adverbs for the SFPs $m o$ and po. As in the case of $\mathrm{C}$, for adverbs it is not evident, either, how to determine their nominal versus verbal nature. Also note that, irrespective of their different etymologies, these particles are all sentence-final and restricted to main non-declarative sentences.
} 
optionality of $n e_{2}$ in $w h$-questions (cf. (18)) and A-not-A questions (cf. (19)). ${ }^{21}$ (For a detailed study of $n e_{2}$, cf. Pan 2007)

(18) Nĩ wèn-le shéi (ne) ?

2SG ask -PERF who FORCE

'(So) whom have you asked?'

(19) Tā dŏng bù dŏng wèntí (ne) ?

3SG understand NEG understand problem FORCE

'(So) does he understand the problem?'

$\mathrm{Ne}$ thus contrasts clearly with $m a$ which is incompatible with wh-questions and A-not-A questions (cf. (16) - (17) above).

Instead, $n e_{2}$ indicates that the question is not one asked "out of the blue", but is a follow-up of the preceding (linguistic or extra-linguistic) context, as indicated in (20) and (21):

(20) Nǐ dŏng le . [CPforce [тт Tā dŏng bù dŏng ] ne ]? 2SG understand Clow 3SG understand NEG understand FORCE

'You understand. (But) does he understand?'

(21) Wǒ wèn-le Zhāngsān. [CPforce [тP Nǐ wèn-le shéi] ne ]?

1SG ask -PERF Zhangsan 2SG ask -PERF who FORCE

'I have asked Zhangsan. (And) whom have you asked?'

$\mathrm{Ne}_{2}$ clearly instantiates a Force head $\mathrm{C}_{2}$, as witnessed by its co-occurrence with the low $\mathrm{C}$ le in the order 'le $n e_{2}$ ' (the opposite order ' $n e_{2} l e$ ' being excluded as expected):

$$
\begin{aligned}
& {[\text { CPforce }[\text { ClowP }[\text { TopP Nà } \quad[\text { TP nı̆ wèn shéi }]] \text { le }] \text { ne }] \text { ? }} \\
& \text { in.that.case } 2 \text { SG ask who Clow FORCE } \\
& \text { 'So whom have you asked?' }
\end{aligned}
$$

To summarize, $n e_{2}$ is a Force head indicating the 'follow-up' nature of the question at hand and selects interrogative TPs (wh-questions and yes/no questions in the A-not-A form). Ma, by contrast, exclusively selects declarative TPs.

The imperative SFP $b a$ is called "advisative" by Chao Yuen Ren (1968:807) because of its "softening" effect. Accordingly, an imperative containing $b a$ is understood as less harsh an order than the corresponding imperative sentence without $b a$ :

(23) [Kuài diănr zǒu] ba !

fast a.bit go FORCE

'Better hurry up and go!'

(24) [Zánmen jiù zhème bàn] ba!

1PL then so do FORCE

'Let's just do it that way!'

\footnotetext{
${ }^{21}$ For recent works challenging Cheng's (1991) Clausal Typing Hypothesis, cf. Bruening (2007) and Bruening \& Tran (2006).
} 
Again, the rigid ordering with respect to the low $\mathrm{C}$ le indicates $b a$ 's status as a Force head above the low CP:

(25) [CPforce [CPlow [TP Nǐ bù yòng gěi qián ] le ] ba ]/*le ba.

2SG NEG need give money Clow FORCE/ Clow FORCE

'Then you won't need to pay!' (Chao Yuen Ren 1968:807; example slightly changed)

\section{3. $C_{3}$ heads expressing the speaker/hearer's attitude}

The outermost, i.e. highest $\mathrm{C}$ elements encode the speaker/hearer's attitude, such as ou 'warning reminder' and $a$ 'astonishment' (cf. Chao Yuen Ren 1968:803; 808). Consisting of a single vowel, these SFPs are phonetically fused with a preceding SFP.

(26) Bù zăo l'ou [=le +ou]! Kuài zǒu b'ou [=ba+ou]!

NEG early PART (fusion) fast go PART (fusion)

'It's getting late! Hurry up and go!'

(27) Xiăo Wáng a! [Nǐ hái méi shàng chuáng] a ?!

Xiao Wang PART 2SG still NEG go bed ATT

'Hey, Xiao Wang! Aren't you in bed yet?!'

(28) [Nĩ yě yào qù ] a?

2SG also want go ATT

'You are going as well?' (Did I hear you right?)

As can be seen from the examples, the exact meaning of these SFPs in AttitudeP is difficult to pin down and strongly depends on the context and intonation. This is typical of particles relating to the discourse; evidently, it is not incompatible at all with their analysis as heads in a split CP à la Rizzi (1997 (cf. inter alia Munaro \& Poletto 2006, Haegeman this volume and references therein).

\subsection{SFP as selecting and projecting heads}

As already mentioned above, it is the rigid relative ordering among SFPs which provides evidence for the analysis of a given SFP as either $\mathrm{C}_{1}, \mathrm{C}_{2}$, or $\mathrm{C}_{3}$ in the split $\mathrm{CP}$ configuration 'Attitude $>$ Force $>$ Clow. Below are some additional examples illustrating this point.

The Force heads $m a, n e_{2}$ and $b a$ can only follow, but not precede the low $\mathrm{C}_{1} l e$.

(29) [CPforce [CPlow [тр Tā fā yán ] le ] ma ] ? 3SG issue speech Clow FORCE

'Has he given a speech?

(30) [CPforce [CPlow [тP Tā dào năr qù ] le ] ne ] $\left({ }^{*}\right.$ le $)$ ? 3SG to where go Clow FORCE Clow

'So where has he gone?'

(31) [CPforce [CPlow [тр Nĩ bù yòng gěi qián ] le ] ba ] / *le ba ! 2SG NEG need give money Clow FORCE Clow FORCE 'Then you won't need to pay!' 
Finally, the SFP realizing the highest sub-projection in the split CP, viz. AttP, have to follow the Force heads:

$$
\begin{aligned}
& \text { Kuài zǒu b'ou }[=\mathrm{ba}+\mathrm{ou}] / \text { *ou ba ! } \\
& \text { fast go PART (fusion) FORCE+ATT / ATT FORCE } \\
& \text { 'Hurry up and go!' }
\end{aligned}
$$

The ordering restrictions can be neatly captured in terms of selectional restrictions imposed by the SFP as C heads on their complement (TP or phrase headed by an SFP of a lower subprojection). This implies that SFPs project, in contrast to claims made by Toivonen (2003) and taken up by Biberauer et al. (2009), for whom the alleged non-projecting property of particles in turn confirms their "outlier" status and hence their not "counting" as counterevidence when violating the FOFC. ${ }^{22}$

The selectional restrictions imposed by an SFP are also visible in the choices available to the different heads of a given subprojection. For example, the interrogative Force head $m a$ in general cannot select a CP headed by the low $\mathrm{C}$ láizhe (in contrast to a $\mathrm{CP}$ headed by the low $\mathrm{C}$ le, cf. (29) above), given that láizhe asserts the event in addition to locating it in the recent past:

$$
\begin{array}{r}
\text { *[ForceP [CPlow [TP Tāa fā yán }] \text { láizhe }] \text { ma }] ? \text { (Lü Shuxiang et al. 2000:349) } \\
\text { 3SG issue speech Clow FORCE }
\end{array}
$$

Ma can only combine with láizhe if the resulting question can be interpreted as a rhetorical one and thus yields an interpretation compatible with the assertion mediated by láizhe (see also (12) above):

[Tā gāngcái bù shì hái zài zhèr láizhe] ma ] ?

3SG just.now NEG be still be here Clow FORCE

'Wasn't he still here a moment ago?'

We thus obtain the following architecture for the split CP in Mandarin (abstracting away from linear ordering): $:^{23}$

$$
\text { Attitude }>\text { Force }>\text { C (low) }>\text { TP } \quad(\text { cf. Paul 2006, 2008) }
$$

The main difference with respect to Rizzi's (1997) hierarchy:

$$
\text { Force }>\text { Fin }>\text { TP } \quad(\text { cf. Rizzi 1997) }
$$

\footnotetext{
${ }^{22}$ As pointed out by an anonymous reviewer, particles are explicitly noted as a "recurring", i.e. "predictable" type of exception to the FOFC by Biberauer et al. (2009) and are accordingly assumed to differ in crucial ways from FOFC-respecting complementisers. I fail to see, though, why an exception would count as less of an exception and potential counterevidence when of a recurring type.

${ }^{23}$ The hierarchy does not include the projections TopicP and lián 'even' FocusP also present in the sentence periphery (for a detailed discussion, cf. Paul 2002, 2005 and references therein).

(i) $\quad\left[\mathrm{TopP}_{\text {Z }}\right.$ Zhè-ge wàiguórén ([FocP lián gŏuròu $)[\mathrm{TP}$ tā ([FocP lián gŏuròu) dōu găn chī $\left.\left.]\right]\right]$ this-CL foreigner even dog.meat $3 \mathrm{SG}$ even dog.meat all dare eat

'This foreigner (even dog meat) he dares to eat (even dog meat).'

Note that in Mandarin Chinese focus with 'even' is acceptable both within and outside TP, whereas focus clefts are limited to the TP (cf. Paul \& Whitman 2008).
} 
lies in the presence of the additional head Attitude above Force. Accordingly, the SFPs indicating the sentence type (Force) are not hosted by the highest $\mathrm{C}$ head available.

Note that this situation is not unique to Chinese, but also observable for, for example, West Flemish (cf. Haegeman this volume). Analysing sentence-final and sentence-initial discourse markers as $\mathrm{C}$ heads, Haegeman introduces the projection DiscourseP (above ForceP), comparable to the AttitudeP postulated here for Chinese. As in Chinese, the particles instantiating DiscourseP occur in root contexts only. They are analysed as heads by Haegeman because they may select a particular ForceP and display a rigid order when cooccuring with other particles.

To summarize this section, SFPs have been argued to realize a three-layered split CP, thereby adding Chinese to the languages displaying a highly articulated sentence periphery (along with, for example, Japanese, cf. Endo 2007). In contrast to Rizzi (1997, 2004), but in acordance with later work by inter alia Haegeman and Hill (to appear) and Munaro \& Poletto (2006), the existence of a speaker/hearer-related projection above ForceP (DiscourseP or AttitudeP) needs to be postulated in Chinese as well. Selectional restrictions imposed by the SFPs (on their TP or C-subprojection complement) as well as the rigid ordering observed when they co-occur clearly indicate the head status of SFPs as well as their ability to project. Accordingly, SFPs are full-fledged functional categories located in the sentence periphery. They are not "categorially deficient" as claimed by Biberauer et al. (2009), notwithstanding their surface behaviour as clitics. SFPs in Chinese are thus not comparable - neither functionally nor syntactically - to tag-like or afterthought-like elements such as hey, ok, right conveying the speaker/hearer's involvement illustrated in You want to be careful, hey/right/ok (as suggested by an anonymous reviewer). First, to convey the speaker/hearer's attitude is the function of only one of the three classes of SFP, viz. the outermost class $C_{3}$. Second, the particles in English do not impose selectional restrictions on the TP they combine with and are not sensitive to TP-internal material such as the type of negation. Third, items such as hey, right, ok very probably are adverbs, i.e. XPs, not heads, and do not need to respect a rigid order. Last, but not least, note that SFP (both low $\mathrm{C}$ such as $l e$ and $n e_{1}$ and Force heads such as $m a$ and $b a$ ) are acquired well before the age of two years (cf. Lee Hun-tak Thomas et al. $2005) .^{24}$

\section{The root vs. non-root asymmetry in the Chinese CP}

As mentioned at the beginning of this article, the analysis of the SFPs in Chinese as complementisers proposed here is an extension of the analysis of the yes/no-question marker $m a$ as a complementiser (cf. Lee Hun-tak Thomas 1986, Tang Ting-chi 1988). It is also with respect to the interrogative $m a$ that the limitation to root contexts was explicitly stated for the first time (cf. Li \& Thompson 1981:557, Tang Ting-chi 1988:363ff). Note that so far the literature on the Chinese C-system (from Cheng Lisa Lai-Shen 1991 up to the most recent studies by Li Boya 2006, Xiong Zhongrui 2007, and Hsieh \& Sybesma 2008 among others) has not acknowledged the systematic character of the root/non-root asymmetry and has at best stated the root-only distribution as the idiosyncrasy of an individual SFP (as in the case of $n e$, cf. Cheng Lisa Lai-Shen 1991, Li Yen-Hui Audrey 1992:153), although some of the data underpinning that generalization were observed in earlier work (cf. Li \& Thompson 1981, Tang Ting-chi 1988, Ross 1983). As to be discussed in this section, there are a few cases of

\footnotetext{
${ }^{24}$ Importantly, the children never used the yes/no question $\mathrm{C} m a$ in wh-questions (cf. (16a-b) above)), thus indicating that they had perfectly grasped the selectional restrictions imposed by ma. Incidentally, the early acquisition of SFPs against the background of SVO order also challenges the allegedly "marked" character of socalled "mixed" or"dishamonic" languages and confirms the views expressed by Newmeyer (2005) and Whitman (2008) that considerations of "harmony" are not part of UG; hence not accessible to the child learner.
} 
SFPs occurring in non-root contexts. However, the basic asymmetry between root and nonroot remains valid insofar as there is no split $\mathrm{CP}$ in embedded contexts, where not more than one $\mathrm{C}$ head is licit, if any.

\subsection{Root-only complementisers}

As noted by Li \& Thompson (1981:556-7) and (Tang Ting-chi 1988:363), the yes/no question particle $m a$ cannot be part of an embedded clause, but must always be construed as belonging to the matrix sentence. This is straightforward in (37a): a sentential subject cannot contain $m a$; instead, the 'A-not-A' question form must be used here (37b):

(a) *[Ākiū lái ma ] méi yŏu guānxi.

Akiu come PART NEG have relation

(b) [Ākiū lái bù lái] méi yŏu guānxi.

Akiu come NEG come NEG have relation

'Whether or not Akiu comes doesn't matter.'

In (38a), where the final position of the root clause coincides with the final position of the clausal complement, this 'root only' constraint must be deduced from the interpretational possibilities. As indicated, ma can only question the root clause, not the clausal complement, although zhidao 'know' can also select an interrogative clause (38b). In the case of an embedded interrogative clause (cf. (37b), (38b)), only the 'A-not-A' question is possible.

(a)

\section{[[Tā bù zhīdao [Ākiū lái ]] ma ]? \\ 3SG NEG know Akiu come FORCE}

'Doesn't she know that Akiu is coming?'

[Excluded: 'She doesn't know whether or not Akiu is coming.']

(cf. Li \& Thompson 1981:557; Tang Ting-chi 1988:365)

(b) Tā bù zhīdao [Ākiū lái bù lái].

3SG NEG know Akiu come NEG come

'She doesn't know whether or not Akiu is coming.'

As argued for in Paul (2009), the limitation to root contexts illustrated for the interrogative C $m a$ holds for SFPs in general. Accordingly, they are excluded from relative clauses (39a) and noun complement clauses (40a), which are both subordinated to the head noun by de (itself one of the few [-root] $\mathrm{C}$ to be discussed immediately below): ${ }^{25}$

$$
\begin{aligned}
& \text { a. [DP [тP Zuótiān chī yúròu (*le) de ] rén ] dōu bìng-le. } \\
& \text { yesterday eat fish CLOW SUB person all ill -PERF } \\
& \text { 'The people who ate fish yesterday are all sick.' }
\end{aligned}
$$

\footnotetext{
${ }^{25}$ The allegedly acceptable cases of the SFP le in relative clauses and noun complement clauses provided by an anonymous reviewer (cf. (i) and (ii)) were clearly rejected by my informants:

(i) $\quad\left[{ }_{D P}\left[\right.\right.$ CP-root Juédìng bù măi fángzi $\left({ }^{*} l e\right)$ de $]$ naxie rén $]$ dōu zŏu -le decide NEG buy house Clow SUB those people all leave-PERF

'Those people who have changed their mind and will not buy the house have all left.'

(ii)

[DP[CP-root Lăobăn yào mài gùpiào $(* l e)$ de ] xiāoxi] shì jiă de

boss want sell share Clow SUB news be false DE

'The news that the boss will sell his shares is false.'

(Translation as provided by the reviewer, glosses slightly adapted.)
} 
(slightly changed example from Ross 1983:235)

b. Wŏmen zuótiān chī yúròu le.

1 PL yesterday eat fish CLOW

'We ate fish yesterday.'

(40) a. [DP [TP Xià yŭ $(* 1 e)]$ de xiāoxi $]$. fall rain CLOW SUB news

'The news that it was raining'

b. Xià yŭ le.

fall rain CLOW

'It is raining.'

In general, SFPs are also banned from clausal complements of verbs (41a) and sentential subjects (cf. (37a) above). Note that Mandarin Chinese lacks a $\mathrm{C}$ comparable to that in English heading clausal complements of verbs (42) and sentential subjects (43). ${ }^{26}$

(41) a. Tā gāngcái gàosu wŏ [Ākiū yịjīng líkāi Bẹijīng (*le) ].

$3 \mathrm{SG}$ just tell 1SG Akiu already leave Beijing CLOW

'He just told me that Akiu had already left Beijing.'

b. $\quad$ Ākiū yưjīng líkāi Běijīng le.

Akiu already leave Beijing CLOW

'Akiu had already left Beijing.'

(42)

Tā shuō [Ākiū dé -le jiăng].

3SG say Akiu obtain-PERF award

'She told me that Akiu had won a prize.'

[Ākiū dé -le jiăng] shǐ wŏmen hĕn gāoxìng.

Akiu obtain-PERF award make 1PL very happy

'The fact that Akiu won a prize made us very happy.'

${ }^{26}$ An anonymous reviewer contests this view and refers to the current claim in the literature that a grammaticalized form of the verb shuo 'speak' instantiates such a complementiser (cf. Hsieh \& Sybesma 2008 among many others):

(i) Wŏ zŏngshì juéde shuō, shēnghuó lǐ quē -le diăn shénme

1SG always feel SHUO life in miss-PERF a.bit something

'I have always had the feeling that something is missing in life.'

However, if shuō were really a complementiser, it would be expected to form a constituent with its following TP complement and remain as a block in the case of an afterthought construction, a prediction not borne out by the data. Also note that it is likewise impossible for shuō to follow the verb in (ii) :

(ii) $\quad[(\underline{\text { Shuōo }})$ shēnghuó lī quē -le diăn shénme ], wŏ zŏngshì juéde (*shuo)

SHUO life in miss-PERF a.bit something $1 \mathrm{SG}$ always feel SHUO

'That something is missing in life, I have always thought so.'

Also note that a pause (indicated by a comma) is natural after shuō in (i), but not between shuō and the preceding verb. Last, but not least, in the Chinese literature, none of the numerous papers on shuō or its equivalent in other Sinitic languages has ever provided well-formed examples where the alleged C shuo heads a sentential subject :

(iii) $\quad(\underline{*} \underline{\text { Shuō}})$ shēnghuó lǐ quē -le diăn shénme ] zhēn kěxì

SHUO life in miss-PERF a.bit something really pity

'That something is missing in my life is really a pity.' 
Interestingly, there exist cases where the SFP le is acceptable within a propositional complement and a sentential subject: ${ }^{27}$

$$
\begin{aligned}
& \text { Nĩ wèishénme méi gàosù wŏ [xiào -zhăng bù qù Běijīng le ]? } \\
& \text { 2SG why NEG tell 1SG school-president NEG go Beijing CLOW } \\
& \text { 'Why didn't you tell me that the president doesn't want } \\
& \text { to go to Beijing any more?' }
\end{aligned}
$$

[Xiào -zhăng bù qù Běijīng le ] bù suàn shénme xīnwén. school-president NEG go Beijing CLOW NEG count what news

'That the president doesn't want to go to Beijing any more is no real news.'

Without le, we would obtain a different interpretation for the embedded clause, namely 'that the president doesn't want to go to Beijing'. Accordingly, le seems to be a $\mathrm{C}$ which is acceptable not only in root contexts, but also in non-root contexts, provided no other non-root $\mathrm{C}$ is present (cf. (39a), (40a) above). Let us now turn to the exclusively non-root $\mathrm{C}$ de and dehuà.

\subsection{The exclusively non-root $C$ de and dehuà}

\subsubsection{De in complex DPs vs. de in the propositional assertion construction}

De closing off the relative clause (cf. (39a) above) was analysed as C by Cheng Lisa Lai-Shen (1986). She fails, though, to note the systematic difference between the non-root-only nature of $d e$ in opposition to the other root-only C elements (cf. Paul 2009 for further discussion).

De in the propositional assertion construction is another instance of a non-root $\mathrm{C}$ (cf. Paul \& Whitman 2008): the copula shi 'be' selects a complement headed by de which, in turn, takes as its complement a non-finite TP. As indicated by the translation 'it is the case that...' this construction is used in order to strengthen the assertion of the sentence as a whole:

(46) Wŏ shì [CP(-root) [cónglái bù chōu yān ] de].

1SG be ever NEG inhale smoke C(-root)

'(It is the case that) I have never smoked.'

(47) Wŏ shì [CP(-root) [dào š̃ dōu huì xiăng-zhe nĭ ] de ].

$1 \mathrm{SG}$ be until death all will think-DUR 2SG C(-root)

'(It is the case that) I will think of you until I die.'

(based on example (10) by Li, Thompson \& Zhang 1998:95)

(48) Tā shì [CP(-root) [yīdìng huì [pp duì nĭ ] hăo yī-bèizi ] de ]. 3SG be certainly will towards 2SG good 1-generation C(-root) '(It is the case that) he will certainly be good to you for an entire lifetime.'

(Li, Thompson \& Zhang 1998:94, (C))

\footnotetext{
${ }^{27}$ Thanks to an anonymous reviewer for providing this type of data. Her/his examples were modified in order to render them more natural.
} 


$$
\begin{aligned}
& \text { [TopP [DP Zhèi-ge dōngxī] [TP tā shì [CP(-root) [yīnggāi bān } \quad \text {-de } \quad \text {-dòng top }] \text { de } \quad \text { ]] }]^{28} \\
& \text { this-CL thing } 3 \mathrm{Sg} \text { be must remove-able-move C(-root) }
\end{aligned}
$$

The de in the propositional assertion construction selects a non-finite TP, as witnessed by the obligatory raising of the subject to the matrix subject position, whereas the non-root $\mathrm{C}$ closing off the relative clause selects a finite TP complement. Furthermore, extraction from the complement of $d e$ in the propositional assertion construction is possible (cf. (50)) and clearly contrasts with the non-extractability from a relative clause (cf. (51b)). (For further discussion, cf. Paul \& Whitman 2008, section 6.3):

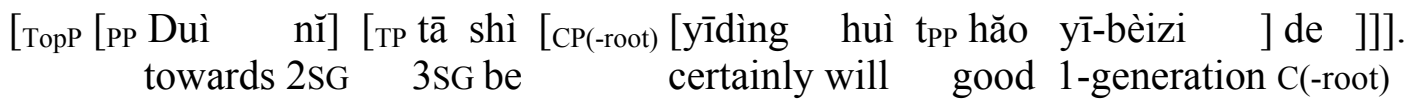

'(It is the case that) he will certainly be good to you for an entire lifetime.'
a. Tā hèn [DP [CP(-root) [TP [Pp duì nì ] huì hăo yī-bèizi ] de ] (rén) ]. 3SG hate towards 2SG will good 1-lifetime C(-root) people 'He hates people/those who will be good to you for an entire lifetime.'

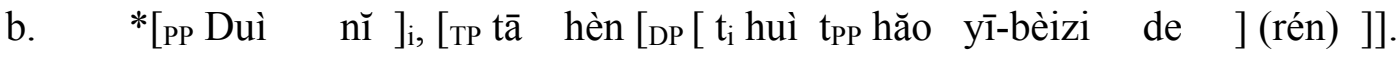 towards 2SG 3SG hate will good 1-lifetime C(-root) people (*‘[To you $]_{i}$, he hates people/those who will be good $t_{i}$ an entire lifetime.')

Last, but not least, de in complex DPs not only subordinates relative and complement clauses to the head noun, but any kind of modifier XP (PP, NP, QP, AP, adverbs) (cf. Paul 2012 for further discussion). This indicates that $d e$ in the complex DP 'XP de NP' and the de in the propositional assertion construction are different heads imposing different selectional constraints on their complements, while sharing non-root $\mathrm{C}$ status. They visibly differ in their feature make-up and should perhaps be treated as homophonous items in the synchronic grammar of Chinese. ${ }^{29}$

Analysing de in the propositional assertion construction as the head of the projection selected by the matrix verb shi 'be' allows us to correctly predict the unacceptability of SFPs within DeP (cf. (52)). Being the clausal complement of the matrix verb shi 'be', DeP represents an embedded context, whence the ban on SFPs. This ban is absolute due to the presence of a non-root $\mathrm{C}$, i.e. $d e$; in this respect, the propositional assertion construction behaves on a par with relative clauses (cf. (39a), (40a) above).

\footnotetext{
${ }^{28}$ As can be seen from the gloss 'able', the de in the verbal compound bān-de-dòng 'be able to move' is a completely different word, not to be confounded with the non-root $\mathrm{C} d e$.

${ }^{29}$ Given this characterization of the two $d e$ 's, I fail to understand why "de in the cited examples clearly doesn't function as a typical clausal subordinator", as stated by an anonymous reviewer. Assuming that that is considered as the prototypical example of a clausal subordinator, because it indicates both the non-root nature of its projection as well as the sentence type (Force), then the de in the propositional assertion construction, conveying assertive force and heading the projection selected as complement by the verb shi 'be', certainly qualifies as such a clausal subordinator, too. As for the de in a complex DP, it is perhaps its "non-selective" nature as witnessed by the fact that all kinds of XPs are subordinated to the head noun by de that underlies the reviewer's reluctance to accept an analysis of $d e$ as C. Note that this selective freedom of $d e$ has so far not been given a satisfying analysis. Cheng Lisa Lai-Shen (1986:319), for example, simply states that "a complementizer, being a head, may or may not select a particular type of complement or specifier. English is an example of a complementizer selecting only I" as its complement. [...] de, if it is a complementizer in Mandarin, places no restrictions on the category of its complement." (p.319). She contents herself with this reformulation of the facts and does not pursue it any further.
} 
[Topp $[\text { Zhèi-ge dōngxī] }]_{i}\left[\right.$ Tp tā shì [CP(-root) [yīnggāi bān $\quad$-de $\quad$-dòng $\left.t_{\mathrm{i}}\left({ }^{*} \mathrm{le}\right)\right]$ de $\left.\left.]\right]\right]$. this-CL thing $3 \mathrm{SG}$ be must remove-able-move Clow C(-root)

'This thing, he should indeed be able to move it.'

Once we acknowledge that $d e$ in the propositional assertion construction heads the complement embedded under the matrix verb, we can account for the co-occurrence of this non-root $\mathrm{C} d e$ with a low root $\mathrm{C}$ (e.g. le), construed with the matrix clause, in the order 'de le':

[CPlow [тP Wèntí xiànzài shì [C(-root) néng jiějué de ] le le ]. problem now be can solve C(-root) Clow

'The problem can certainly be solved now.'

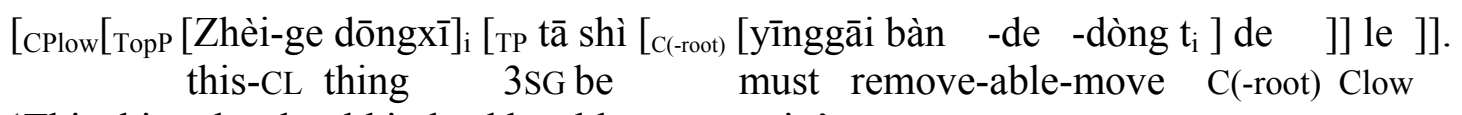

'This thing, he should indeed be able to move it.'

The co-occurrence of the low $\mathrm{C}$ le with $d e$ would not be possible if $d e$ were a low root $\mathrm{C}$ on a par with le and likewise construed with the matrix clause, because SFPs instantiating the same head $\left(\mathrm{C}_{1}, \mathrm{C}_{2}\right.$ or $\left.\mathrm{C}_{3}\right)$ are in a paradigmatic relation to each other and mutually exclusive (cf. Table 1 above). Given that $l e$ instantiates the lowest $\mathrm{C}$ subprojection within the split $\mathrm{CP}$, it cannot be preceded by another root $\mathrm{C}$.

\subsubsection{Non-root C dehuà}

Dehuà heading conditional clauses is another non-root C. Following Gasde \& Paul (1996), conditional clauses are analysed as clausal topics located in SpecTopP:

[CPlow [Topp [C(-root) Ākiū jīntiān líkāi Běijīng (*le) dehuà]

Akiu today leave Beijing Clow C(-root)

[тP tā hěn kuài jiù yào dào ]] le ].

3SG very fast then will arrive Clow

'If Akiu has left Beijing today, then he should be here very soon.'

$$
\begin{aligned}
& \text { [CPlow [Topp [C(-root) Rúguŏ xià yŭ (*le)] dehuà] [tp wŏ jiù bù qù]]]. } \\
& \text { if fall rain Clow C(-root) 1SG then NEG go } \\
& \text { 'If it rains, then I won't go.' }
\end{aligned}
$$

Again, no SFPs are allowed within the projection headed by dehuà, exactly as in the case of the projections headed by de (both in a complex DP and the propositional assertion construction).

The analysis of dehuà as a non-root $\mathrm{C}$ is confirmed by its behaviour in the so-called "afterthought construction" (cf. Chao Yuen Ren 1968, Lu Jianming 1980): ${ }^{30}$

$$
\begin{aligned}
& \text { a. [CP Lái -le ma ], nı̆ gēge (*ma) ? (Lu Jianming 1980) } \\
& \text { come-PERF FORCE 2sG brother FORCE } \\
& \text { 'Has he come, your brother?' }
\end{aligned}
$$

\footnotetext{
${ }^{30}$ As observed by Chao Yuen Ren (1968:132), the afterthought part is likely to be read at a faster tempo, the preceding part constituting the main clause.
} 


\section{b. [тр Nǐ gēge lái -le ] ma ? 2SG brother come-PERF FORCE 'Has your brother come?'}

As evidenced by the position of $m a$ in $(57 \mathrm{a})$, the constituent representing the "afterthought" part is adjoined to the right of the CP.

When the clause headed by dehuà plays the role of such an afterthought (cf. (58b)), crucially, dehuà is retained, confirming that rúguŏ tã lái dehuà forms a constituent (CP): ${ }^{31}$

a. Rúguŏ tā lái dehuà, wŏ jiù bù cānjiā huìyì le.

if $3 \mathrm{SG}$ come C(-root) $1 \mathrm{SG}$ then NEG attend meeting CLOW

'If he comes, then I won't attend the meeting.'

b. Wŏ bù cānjiā huìì le, rúguŏ tā lái dehuà.

$1 \mathrm{SG}$ NEG attend meeting CLOW if $3 \mathrm{SG}$ come C(-root)

'I won't attend the meeting, if he comes.'

The non-root $\mathrm{C}$ dehuà must therefore be distinguished from particles (optionally) heading TopicP such as $m e$, ne, etc.: ${ }^{32}$

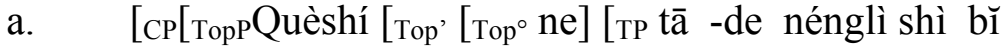 indeed TOP 3SG-SUB ability be compared.with 1SG strong 'His abilities are indeed greater than mine.'
b. [СР [тр Tā -de nénglì shì bĭ wǒ qiáng] $]$ quèshí (*ne).
3SG-SUB ability be compared.with 1SG strong indeed TOP
'His abilities are greater than mine, indeed.' wǒ qiáng]]]].

A particle such as ne instantiating the head Topic selects a TP-complement to its right (or another TopP, giving rise to multiple topics), whence the observed unacceptability of these topic particles in the afterthought part.

This analysis is confirmed by the co-occurrence of dehuà with a Top ${ }^{\circ}$, which would be impossible if dehuà were a Top ${ }^{\circ}$ itself. For a topic XP can only be followed by one particle realizing Top $^{\circ}$ at a time (cf. Paul 2006 for further discussion):
a. $\quad\left[\right.$ TopP $\left[\mathrm{C}(-\right.$-root) $[$ Yàoshì xià yŭ $]$ dehuà $]\left[\mathrm{Top}^{\prime}\left[\mathrm{Top}^{\circ} \underline{\text { ne }}\right][\mathrm{TP}\right.$ wŏ jiù bù qù $\left.\left.]\right]\right]$. if fall rain C(-root) TOP 1SG then NEG go
'If it rains tomorrow, I won't go.'

\footnotetext{
${ }^{31}$ Incidentally, the unacceptability of the adverb jiù 'then' in the main clause in (58b), repeated in (i), argues against a derivation of the afterthought construction via right dislocation and confirms the adjunction to $\mathrm{CP}$ analysis proposed here. (For further discussion, cf. Gasde \& Paul 1996, Paul 2009.)

(i) Wǒ (*jiù) bù cānjiā huìyì le, rúguŏ tā lái dehuà

$1 \mathrm{SG}$ then NEG attend meeting CLOW if $3 \mathrm{SG}$ come C(-root)

'I won't attend the meeting, if he comes.'

${ }^{32}$ The co-occurrence of the topic head ne and Clow ne in the same sentence confirms their distinct categorial status:

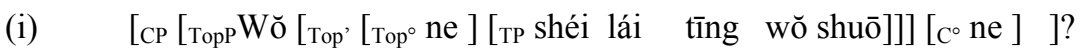

$$
1 \mathrm{SG} \text { TOP who come listen } 1 \mathrm{SG} \text { say FORCE }
$$

'And me, who will listen to what I say?'

This illustrates that there are several homophonous items ne realizing different categories.
} 
b. Wŏ bù qù , [C(-root) [yàoshì xià yŭ ] dehuà ] (* ne).

1SG NEG go if fall rain C(-root) TOP

'I won't go, if it rains tomorrow.'

Last, but not least, note that extraction of arguments from the conditional clause headed by dehuà is allowed:

a. $\quad\left[\mathrm{TopP}_{\mathrm{CP}}[\mathrm{-root})[\mathrm{TP} \mathrm{N} \check{\mathrm{N}}[\mathrm{PP}\right.$ duì Lìsì $]$ yǒu yìjiàn $]$ dehuà $]$

2SG towards Lisi have prejudice C(-root)

[TopP nà [TP Wǒmen bìxū zhăo lìngwài ȳ̄-ge rén ]]].

then 1PL need search else 1 -CL person

'If you are prejudiced against Lisi, then we need to look for somebody else.'

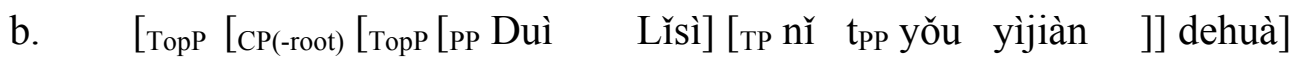
towards Lisi 2SG have prejudice $\mathrm{C}$ (-root)

[Topp nà [TP wǒmen bìxū zhăo lìngwài yī-ge rén ]]]. then 1PL need search else 1 -CL person

'If you are prejudiced against Lisi, then we need to look for somebody else.'

Dehuà is thus on a par with the non-root $\mathrm{C}$ de in the propositional assertion construction where extraction is also allowed (cf. (50) above). It contrasts sharply with the non-root $\mathrm{C} d e$ in relative clauses, from which extraction is barred (irrespective of the presence/absence of the head noun, i.e. huà 'words'):

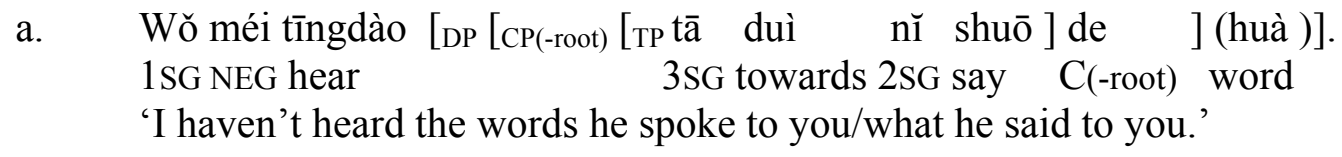

b. * $\quad$ [PP Duì nì ] [TP wǒ méi tīngdào [DP [CP(-root) [TP tā t tPP shuō ] de ] (huà)]. towards 2SG 1SG NEG hear 3SG say C(-root) word

Given that a complex DP headed by huà 'words' and containing a relative clause can probably be postulated as the source structure for the non-root $\mathrm{C}$ dehuà, the contrast between (62) and (61) illustrates that the reanalyzed item does not automatically retain the features of its source.

To summarize, this section has introduced the so far neglected, exclusively non-root $\mathrm{Cs}$ de and dehuà. They contrast with the other $\mathrm{C}$ heads, which are limited to root contexts. Only the low $\mathrm{C}$ le seems to be acceptable in an embedded context as well. Crucially, this is only possible in the absence of any other non-root $\mathrm{C}$; as soon as either de or dehuà are present, no other $\mathrm{C}$ is allowed. In other words, non-root contexts do not display a split $\mathrm{CP}$, but only one $\mathrm{C}$ layer, as opposed to the three-layered split $\mathrm{CP}$ in root contexts. This illustrates the fundamental root vs. non-root asymmetry at work in the Chinese C-system.

Just one brief remark on the FOFC. Given that in more recent work (cf. Biberauer, Holmberg \& Roberts 2010:82), this constraint is supposed to hold for C in embedded clauses only, the existence of the non-root $\mathrm{C}$ de and dehua is important since they underminethe predictions made by the FOFC. Note in this context that in earlier stages of Chinese, the interrogative clause-final $\mathrm{C} h \bar{u}$ for yes/no questions occurred both in root and embedded questions (cf. (63a-b)), again giving rise to the structure precisely excluded by the FOFC: 
a. Wŏ bù shì [CP(-root) [тp pro néng zhì fŏu ] hū ]. (Mengzi (2B2); 1SG NEG know can arrive not.be FORCE 4th-3rd c. BC) 'I don't know whether he will be able to go there or not.'

b. Bù zhī [CP(-root) [TP tiān qì Lŭ $]$ hū $]$. NEG know heaven abandon Lu FORCE

(Shiji 33; 1542; 'I do not know whether Heaven has abandoned [the state of] Lu.

Furthermore, other SFPs at that period might likewise turn out to be able to occur both in matrix and embedded contexts (cf. Djamouri, Meisterernst \& Paul 2009), suggesting that the root vs. non-root asymmetry observed for Modern Mandarin is a more recent phenomenon.

\section{Subordinating conjunctions in Chinese}

So far I have concentrated on providing evidence for the C status of SFPs in Chinese and on exploring the syntactic and semantic constraints in the split CP. In this section, I turn to the equivalents in Chinese of English subordinating conjunctions such as although, because, if, whose status is still controversial. It is beyond the scope of this article to solve this problem; instead, I will only discuss those issues that allow me to demonstrate that SFPs and conjunctions in Chinese belong to different syntactic categories.

\subsection{The categorial heterogeneity of so-called subordinating conjunctions}

The attentive reader may have noticed the items rúguŏ and yàoshi glossed as 'if' in examples (56), (58) and (60) above and may have wondered whether these are not precisely clauseinitial subordinating conjunctions complying with the FOFC:

$$
\begin{gathered}
\text { [CPlow [Topp [C(-root) }[\text { Rúguo tā lái ] dehuà] [wŏ jiù bù cānjiā huìì ] ] le ]. } \\
\text { if } 3 \mathrm{SG} \text { come C(-root) } 1 \mathrm{SG} \text { then NEG attend meeting CLOW } \\
\text { 'If he comes, then I won't attend the meeting.' }
\end{gathered}
$$

Furthermore, this type of example where both rúguó 'if' and the non-root $\mathrm{C}$ dehuà are present seems at first sight to confirm a reviewer's view that SFPs are just the particle counterpart of a "full" element expressing a similar meaning, where this full element obeys the FOFC (cf. Biberauer et al. 2010, p.53ff for a similar view). However, a closer examination reveals a quite different picture.

First, the "doubling" observed in the case of conditional clauses is unique, and there are no "corresponding full" counterparts for the numerous $\mathrm{C}$ heads discussed in section 3 above.

Second, a conditional clause is also acceptable with either the non-root C dehuà or yàoshi/rúguŏ 'if' on their own:

(65) a. Tā lái dehuà, wŏ jiù bù cānjiā huìyì le. 3SG come C(-root) 1SG then NEG attend meeting CLOW

b. Rúguo tā lái, wŏ jiù bù cānjiā huiyì le. if $3 \mathrm{SG}$ come $1 \mathrm{SG}$ then NEG attend meeting CLOW 'If he comes, then I won't attend the meeting.' 
In fact, conditional clauses are special insofar as they do not need any overt marking, but are identifiable as such qua their position in SpecTopP:

$$
\begin{aligned}
& \text { [TорР [тр Tā lái ] [TP(root) Wŏ bù lái ]]. } \\
& \text { 3SG come 1SG NEG come } \\
& \text { 'If he comes, I will not come.' }
\end{aligned}
$$

Third, besides yàoshi and rúguo, the Chinese equivalents for English subordinating conjunctions such as suīrán 'although', jìrán 'since', yīnwèi 'because', zìcóng 'since (temporal)' do not have a "counterpart" SFP. Importantly, this group is not homogeneous, but in fact comprises (sentence-level) adverbs, on the one hand, and heads (prepositions), on the other. $^{33}$

As Lu Peng (2003, 2008) has argued for in great detail, rúguŏ/yàoshi 'if', suìrán 'although', and jirán 'since' are sentence-level adverbs on a par with, for example, xiănrán 'obviously, naturally', xìnghăo 'fortunately', kěxi 'unfortunately' etc. Note that in Chinese, sentence-level adverbs can occur to the left or to the right of the subject. More precisely, they pattern with (DP) topics occupying the external or the TP-internal topic position (SpecTopP) (cf. Paul 2002, 2005). For reasons of space, this will be shown only for the pair xinghăo 'fortunately' and rúguŏ 'if' (for further discussion, see Lu Peng 2003, 2008, section 3.2):
a. [ext.Topp Xìnghăo [TP Wŏ [int.TopP nà -fù huà [AspP mài-le ge gāo jià]]]]. fortunately $1 \mathrm{SG}$ that-CL painting sell-PERF CL high price 'Fortunately, I sold that painting at a high price.' (Lu Peng 2008:164)

b. [TP Wŏ [int.TopP xìnghăo [int.Topp nà -fù huà [AspP mài-le ge gāo jià ]]]]. 1SG fortunately that-CL painting sell-PERF CL high price

c. [TP Wŏ [int.TopP nà -fù huà [int.TopP xìnghăo [AspP mài-le ge gāo jià ]]]]. 1SG that-CL painting fortunately sell-PERF CL high price

As illustrated in (67b-c), the DP nà-fù huà 'that painting' and the sentence-level adverb xìnghăo 'fortunately' are interchangeable, both being internal topics. (68) below shows rúguŏ 'if' to have the same distribution as xinghăo 'fortunately':
a. $\quad \underline{\text { Rúguŏ }}$ [TP nǐ [int.TopP yīngyǔ kăoshì [AuxP néng kăo ge dìyī ]]] if 2SG English exam can pass CL first wŏ jiù jiănglì nĭ ȳ̄-liàng xīn zìxíngchē.
1SG then award 2SG 1-CL new bicycle
'If in the English exam you can pass with a first, I'll reward you with a bicycle.'

\footnotetext{
${ }^{33}$ With respect to the $\mathrm{P}$ versus $\mathrm{C}$ status of subordinating conjunctions, I follow the general consensus that items with lexical content such as 'because', 'since', etc. are analysed as P. In English, these prepositions behave differently from Cs such as that and if in that they allow sluicing:

(i) I left before Bill left, but Jane left after [e]

(ii) *I know that/if Bill left, but Jane doesn’t know that/if [e]

Thanks to John Whitman for discussion of this point.

Huang C.-T. James (1982:85) left open the P versus C status of items such as yinwwè 'because', concentrating on the head-initial character of their projection. Note that he analysed rúguŏ 'if' and suīrán 'although' as P/C-heads on a par with yīnwèi 'because', an analysis which remained unchallenged up to Lu Peng's (2003) dissertation, which is discussed in the main text.
} 
b. Nĭ rúguŏ yīngyǔ kăoshì néng kăo ge dìȳi ...

2SG if English exam can pass CL first

'If in the English exam you can pass with a first, ...'

c. Nũ yīngyǔ kăoshì rúguŏ néng kăo ge dìȳ̄...

2SG English exam if can pass CL first

'If in the English exam you can pass with a first,...'

Accordingly, rúguŏ 'if' is not a head and the following clause is not its complement. Instead, rúguó is a sentence-level adverb which shows the same distribution as DP topics, viz. it occupies the specifier of the TP-external or TP-internal TopP. ${ }^{34}$

In contrast, yinwèi 'because', zicóng 'since (temporal)', etc. are heads and accordingly restricted to the position preceding their complement clause:

(69) a. [PP Ȳinwèi [TP Zhāng Sān zuótiān méi shōudào nà -fēng xìn ]] because Zhang San yesterday NEG receive that-CL letter wǒ jīntiān gěi tā fā -le fèn chuánzhēn 1SG today for 3SG send-PERF CL fax.

'Since Zhang San didn't receive the letter yesterday, I sent him a fax today.'

b. *Zhāng Sān [рт yīnwèi [тр Zuótiān méi shōudào nà -fēng xìn ]] Zhang San because yesterday NEG receive that-CL letter wŏ jīntiān gěi tā fā -le fèn chuánzhēn. $1 \mathrm{SG}$ today for $3 \mathrm{SG}$ send-PERF CL fax

(Lu Peng 2008:131)

The fact that constituents to the left of the P-heads yinwèi 'because', zicóng 'since (temporal)' etc. are clearly outside the causal/temporal clause is further illustrated in (70):

(70) * Zuótiān [рр yīnwèi [тр Zhāng Sān méi shōudào nà -fēng xìn ] yesterday because Zhang San NEG receive that-CL letter wǒ jīntiān gěi tā fā -le fèn chuánzhēn.

1SG today for 3SG send-PERF CL fax

(Lu Peng 2008:182)

Zuótiān 'yesterday' can only be construed as a matrix topic here and is then in contradiction with jintiān 'today' in the matrix TP.

(70) thus contrasts sharply with (71a) where mingtiān 'tomorrow' to the left of rúguó is part of the conditional clause (in SpecTopP), as shown by its compatibility with houtian 'the day after tomorrow' in the matrix TP:

(71) a. [Míngtiān rúguŏ Zhāng Sān hái méi shōudào nà -fēng xìn ] tomorrow if Zhang San yet NEG receive that-CL letter wŏ hòutiān gěi tā fā fèn chuánzhēn.

1SG day.after.tomorrow for 3SG send CL fax

'If tomorrow Zhang San still hasn't received the letter, I'll send him a fax

\footnotetext{
${ }^{34}$ While semantically the sentence-level adverb rúguó 'if' may fulfill a function similar to that of the non-root $\mathrm{C}$ dehuà, it clearly belongs to a different syntactic category. To talk about "particle and non-particle counterparts of 'the same' category of element" as Biberauer et al. (2010:54) do therefore does not seem appropriate.
} 
the day after tomorrow.'

b. [Rúguŏ Zhāng Sān míngtiān hái méi shōudào nà -fēng xìn ]

if Zhang San tomorrow yet NEG receive that-CL letter

wŏ hòutiān gěi tā fā fèn chuánzhēn.

1SG day.after.tomorrow for 3SG send CL fax

'If tomorrow Zhang San still hasn't received the letter, I'll send him a fax

the day after tomorrow.'

(Lu Peng 2008:183)

The acceptability of (71a) is thus on par with that of (71b) where mingtiān occurs to the right of rúguŏ and the subject DP.

\subsection{Chinese "subordinating conjunctions" and WALS' "adverbial subordinator"}

We have seen that the Chinese equivalents for English subordinating conjunctions are not a homogeneous group, but instantiate different categories, i.e. sentence-level adverbs (e.g. rúguŏ 'if', suìrán 'although', jìrán 'since'), on the one hand, and prepositions (e.g. yìnwèi 'because', zicóng 'since (temporal)'), on the other. Incidentally, the latter comply with the FOFC, taking their (TP) complement to the right, while the former are simply not relevant as they are not heads.

Importantly, the heterogeneous nature of "conjunctions" in Chinese again highlights the problematic character of the re-interpretation of WALS' term adverbial subordinator as C by Biberauer et al. (2009). While for the conjunctions with head status such as yinwèi 'because' a C-status rather than P-status does admittedly not make much difference with respect to the parameter examined, i.e. the relative order between head and complement, an analysis in terms of $\mathrm{C}$ (or any other functional head) can in no way be extended to the sentence-level adverbs such as rúguŏ 'if'. However, both classes would certainly be considered as "adverbial subordinators" by WALS if Chinese were included in their data base for the relevant Feature 94. And the cases where these adverbs occupy the external topic position to the left of the subject (cf. (65b) above) would then incorrectly count as instances of the order 'adverbial subordinator - clause', with the adverbial subordinator assigned the status of a head. ${ }^{35}$

Given these problems which emerge within a single language, here Mandarin Chinese, it does not need much fantasy to realize that difficulties of this kind increase exponentially when including more languages. As a consequence, the results for the distribution of adverbial subordinator in WALS cannot serve as a testing ground for the FOFC. Closer examination of each of the more than 600 languages included for Feature 94 is likely to uncover quite a number of cases which will have to be crossed off the list of potential $\mathrm{C}$ elements, thus weakening the at first sight statistically solid empirical basis for FOFC. (Recall Dryer's inventory of rather disparate items considered as adverbial subordinators in WALS, as discussed in section 2.1 above.)

To summarize this section, we have seen that the equivalents of subordinating conjunctions such as because, since, if, etc. in Chinese turn out to be either sentence-level adverbs or prepositional heads, and thus differ from the SFPa instantiating the heads of the subprojections in the split CP. Even if the conjunctions with head status such as yinwei 'because' and zicóng 'since (temporal)' were analysed as $\mathrm{C}$ rather than $\mathrm{P}$, they would still have to be distinguished from the class of $\mathrm{C}$ elements realized by SFPs, given the differences

\footnotetext{
${ }^{35}$ Probably, Mandarin would then count as a language displaying "mixed order" for adverbial subordinator and clause, on a par with Cantonese, which - unlike Mandarin - is included in the database for Feature 94.
} 
in selectional restrictions for each class. For instance, yinwèi 'because' and zicóng 'since (temporal)' do not seem to impose contraints on the extended VP in their complement clause (in terms of type of negation, aktionsart etc.), in contrast to what we have observed for the low Cs le, láizhe, $n e_{1}$ (cf. section 3.1 above). We would then simply obtain two classes of Cs with different (surface) head directionality, parallel to the two classes of adpositions (pre- and postpositions) present in Chinese (cf. Djamouri, Paul \& Whitman 2009, 2013b). Importantly, such a scenario would in no way challenge the status of SFPs as selecting and projecting $\mathrm{C}$ heads defended here.

\section{Conclusion}

SFPs in Chinese have been analysed as heads of the subprojections in a three-layered split CP:Attitude $>$ Force $>$ Clow $>$ TP. The C-system in Chinese is characterized by a root vs. nonroot asymmetry because the large majority of Cs are limited to root contexts. In non-root contexts, only dehuà heading conditional clauses, $d e$ in the propositional assertion construction and de in complex DPs subordinating clauses to the head noun are attested. Crucially, there is no split CP in non-root contexts, where not more than one $\mathrm{C}$ is licit, if any.

Being projecting and selecting heads, SFPs are clearly not "categorially deficient" (cf. Biberauer et al. 2009) or "syncategorematic" (cf. Biberauer et al. 2010:.81, section 5.1.2). ${ }^{36}$ Nor are they unable to be "syncretic" like, for example, English if, which indicates both subordination and interrogativity (cf. Biberauer et al. 2010:55). Quite on the contrary, in addition to an obligatory value for [ \pm root] (parallel to the 'subordination' component in if), SFPs always involve other specifications: láizhe expresses both 'recent past' and 'event assertion', ne interrogativity and the fact that this is a follow-up question, ma interrogativity and (optionally) a bias what answer to expect (in contrast to the exclusively neutral 'A-not $\mathrm{A}$ ' question); last, but not least, dehuà is compatible with conditions of all kinds except the necessary and sufficient condition 'iff' (cf. Lu Peng 2008:30).

It is precisely the "syncretic nature" (to use Biberauer et al.'s 2010 term) of SFPs, i.e. the fact that an SFP is characterized by a complex bundle of semantico-syntactic features, that makes it difficult to determine the precise feature make-up for each SFP. As this paper has attempted to show, its effects in terms of syntactic constraints and felicity conditions are, however, clearly observable.

\section{REFERENCES}

АвоH, Enoch Oladé. 2006. Complementation in Saramaccan and Gungbe: the case of C-type modal particles. Natural Language and Linguistic Theory 24.1, 1-55.

ALDRIDGE, Edith 2011. Neg-to-Q: The historical development of one clause-final particle in Chinese. The Linguistic Review 28: 411- 447.

Biberauer, Theresa, Holmberg, Anders \& Roberts, Ian. 2007. Disharmonic word order systems and the Final-over-Final Constraint (FOFC). Proceedings of XXXIII Incontro di Grammatica Generativa, ed. Antonietta Bisetto \& Francisco Barbieri, 86-105. Bologna: Dipartimento di Lingue e Letterature Straniere Moderne.

\footnotetext{
${ }^{36}$ Biberauer et al (2010, section 5.1.3) define syncategorematic elements as follows: they are "(i) not c-selected, (ii) do not select, (iii) (therefore) occupy no fixed position in the clausal hierarchy; (iv) have surface scope determined by their position; (v) may violate consistent word-order patterns of the language; (vi) may violate the FOFC". Curiously enough, they consider the Chinese Force head ma as such a "syncategorematic" element, while remaining silent about the status of the numerous other root-Cs in Chinese.
} 
Biberauer, Theresa, Holmberg, Anders \& Roberts, Ian. 2008. Structure and linearization in disharmonic word orders. Proceedings of the 26th West Coast Conference on Formal Linguistics. eds. In Charles B. Chang \& Hannah J. Haynie, 96-104. Somerville, MA: Cascadilla Proceedings Project.

Biberauer, Theresa, Holmberg, Anders \& Roberts, Ian. 2010. A syntactic universal and its consequences. Unpublished ms., University of Cambridge.

Biberauer, Theresa, / Newton, Glenda \& Sheehan, Michelle 2009. Limiting synchronic and diachronic variation and change: The Final-over-Final Constraint. Language and Linguistics 10.4, 701-743.

BRUENING, Benjamin 2007. Wh-in-situ does not correlate with wh-indefinites or question particles. Linguistic Inquiry 38.1, 139-166.

BRUENING, Benjamin \& Tran, Thuan 2006. Wh-questions in Vietnamese. Journal of East Asian Linguistics 15, 319-341.

Cecchetto, Carlo (2013). Backward dependencies must be short. A unified account of the Final-over-Final and the Right Roof Constraints and its consequences for the syntax/ morphology interface. Challenges to Linearization, ed. Theresa Biberauer \& Ian Roberts, 57-92. Berlin: Mouton de Gruyter

CHAO, Yuen Ren. 1968. A grammar of spoken Chinese. Los Angeles: California University Press.

CHEN, Qianrui 2005. Laizhe de fazhan yu zhuguanhua [The development of laizhe and subjectivization]. Zhongguo Yuwen 2005, no. 4, 308-319.

Cheng, Lisa Lai-Shen. 1986. De in Mandarin. Canadian Journal of Linguistics 31, 313-326.

CHENG, Lisa Lai-Shen 1991. On the typology of wh-questions. MIT: Ph.D. dissertation.

DJAMOURI, Redouane. 1988. Etude des formes syntaxiques dans les écrits oraculaires gravés sur os et écaille de tortue (Chine $14^{e}-11^{e}$ av. J.-C.). Ecole des Hautes Etudes en Sciences Sociales, Paris: Ph.D. dissertation.

DJAmouri, Redouane, Meisterernst, Barbara \& Paul, Waltraud. 2009. Particles in Classical Chinese: complementisers and topic markers. Paper presented at the 29th International Conference on Historical Linguistics, Radboud Universiteit, Nijmegen, 10-14 August 2009.

DJAMOURI, Redouane \& PAUL, Waltraud. 2009. Verb-to-preposition reanalysis in Chinese. Historical syntax and linguistic theory, ed. Paola Crisma \& Giuseppe Longobardi, 194-211. Oxford: Oxford University Press.

DJAmOURI, Redouane, PAUL, Waltraud \& WHITMAN, John. 2008. SVO forever: The case of Chinese. Paper presented at the Conference on Continuity and Change in Grammar, University of Cambridge, 18-20 March 2008.

DJAMOURI, Redouane, PAUL, Waltraud \& WHITMAN, John. 2009. Harmonic disharmony: The case of Chinese adpositions. Paper presented at the Conference on Theoretical Approaches to Disharmonic Word Orders, University of Newcastle, 30 May - 1 June 2009.

DJAmouri, Redouane, Paul, Waltraud \& Whitman, John. 2013a. Syntactic change in Chinese and the argument - adjunct asymmetry. Breaking down the barriers: Interdisciplinary studies in Chinese linguistics and beyond, ed. Cao, Guangshun, Chappell, Hilary, Djamouri, Redouane \& Wiebusch, Thekla. Taipei: Academia Sinica.

DJAmouri, Redouane, PAul, Waltraud \& Whitman, John. 2013b. Postpositions vs. prepositions in Mandarin Chinese: the articulation of disharmony. Theoretical approaches to disharmonic word orders, eds. T. Biberauer \& M. Sheehan. Oxford: Oxford University Press.

DRYER, Matthew S. 1980. The positional tendencies of sentential noun phrases in universal grammar. Canadian Journal of Linguistics 25, 123-195. 
DRYER, Matthew S. 1992. The Greenbergian word order universals. Language 68.1, 81-138.

DRYER, Matthew S. 2008a. Position of polar question particles. The World Atlas of Language Structures Online, chapter 92. ed. Martin Haspelmath, Matthew S. Dryer, David Gil \& Bernard Comrie. Munich: Max Planck Digital Library. [Available online at http://wals.info/feature/92. Accessed on 24.02.2010].

DRYER, Matthew S. 2008b. Order of adverbial subordinator and clause. The World Atlas of Language Structures Online, chapter 94, ed. Martin Haspelmath, Matthew S. Dryer, David Gil \& Bernard Comrie. Munich: Max Planck Digital Library. [Available online at http://wals.info/feature/94. Accessed on 24.02.2010].

DRYER, Matthew S. 2009. The branching direction theory revisited. Universals of Language today, ed. Sergio Scalise, Elisabetta Magni \& Antonietta Bisetto, 185-207. Berlin: Springer.

ENDO, Yoshio. 2007. Locality and information structure: A cartographic approach to Japanese. Amsterdam: Benjamins.

ERNST, Thomas 1988. Chinese postpositions? again. Journal of Chinese Linguistics 16.2, 219-245.

ERNST, Thomas. 1995. Negation in Mandarin Chinese. Natural Language and Linguistic Theory 13.665-707.

GASDE, Horst-Dieter \& PAUL, Waltraud. 1996. Functional categories, topic prominence, and complex sentences in Mandarin Chinese. Linguistics 34.2, 263-294.

GREENBERG, Joseph. 1963. Some universals of grammar with particular reference to the order of meaningful elements. Universals of language, ed. Joseph Greenberg, 58-90. Cambridge, MA: MIT Press.

HAEgeman, Liliane (this volume). West Flemish verb-based discourse markers and the articulation of the speech act layer.

HAEgEMAN, Liliane \& HiLl, Virginia. (to appear). The syntacticization of discourse. Syntax and its limits, eds. Raffaella Folli, Christina Sevdali \& Robert Truswell, chapter 18. New York \& Oxford: Oxford University Press.

Haspelmath, Martin, Dryer, Matthew, Gil, David \& Comrie, Bernard (eds.). 2008. The World Atlas of Language Structures Online [http://wals.info]. Munich: Max Planck Digital Library.

HAwKINS, John. 1983. Word Order Universals. New York: Academic Press.

HAWKINS, John (ed.) 1990. Explaining language universals. Oxford: Oxford University Press.

HsiEH, Feng-Fan. \& SYBESMA, Rint P.E. 2008. Shēngchéng yǔfa lǐlùn hé Hànyǔ yǔqì yánjiū [Generative grammar and the study of sentence final particles in Chinese]. Dangdai yuyanxue lilun he hanyu yanjiu [Contemporary linguistic theories and related studies on Chinese], ed. Shen, Yang \& Feng, Shengli, 364-374. Peking: Shangwu.

HSIEH, Miao-Ling. 2001. Form and meaning: negation and question in Chinese. University of Southern California, Los Angeles: Ph.D. dissertation.

Hu, Mingyang. 1981. Beijinghua de yuqi zhuci he tanci [Mood particles and interjections in the Beijing dialect]. Zhongguo Yuwen 5, 347-350; 6, 416- 423.

HuAnG, C.-T. James 1982. Logical Relations in Chinese and the theory of grammar. MIT: Ph.D. dissertation.

HuANG, C.-T. James 1984. On the distribution and reference of empty pronouns. Linguistic Inquiry 15.4, 531-574.

JIANG, Haiyan 2008. Yuqici $b a$ he yiwen yuqi de chuanda [The auxiliary word $b a$ and the interrogative mood]. Paper presented at the 16th Annual Meeting of the International Association of Chinese Linguistics, University of Beijing, 30 May - 1 June, 2008.

KAYNE, Richard S. 1991. Romance clitics, verb movement and PRO. Linguistic Inquiry 22.4, 647-686. 
LEE, Hun-tak Thomas. 1986. Studies on quantification in Chinese. University of California at Los Angeles: Ph.D. dissertation.

LEE, Hun-tak Thomas et al. 2005. The acquisition of sentence-final particles in Beijing Mandarin. Paper presented at the Thirteenth Annual Meeting of the International Association of Chinese Linguistics, University of Leiden, 9-11 June, 2005.

LI, Boya. 2006. Chinese final particles and the syntax of the periphery. University of Leiden: $\mathrm{Ph} . \mathrm{D}$. dissertation.

Li, Charles N. \& ThOmpson, Sandra A. 1981. Mandarin Chinese. A functional reference grammar. Los Angeles: California University Press.

Li, Charles N., ThOmpson, Sandra A. \& ZHAng, Bojiang. 1998. Cong huayu jiaodu lunzheng yuqici de [The particle de as an evidential marker in Chinese]. Zhongguo Yuwen 1998, no. 2, 93-102.

LI, Yen-Hui Audrey. 1992. Indefinite wh in Mandarin Chinese. Journal of East Asian Linguistics, 1.2, 125-155.

LIN, Jo-wang. 2003. Aspectual selection and negation in Mandarin Chinese. Linguistics 41.3, 425-459.

LIN, Tzong-Hong Jonah. 2001. Light Verb Syntax and the Theory of Phrase Structure. University of California at Irvine: Ph.D. dissertation.

LU, Jianming. 1980. Hanyu kouyu jufa li de yiwei xianxiang [Permutation phenomena in the grammar of spoken Chinese]. Zhongguo Yuwen 1980, no. 1, 28-41.

LU, Peng. 2003. La subordination adverbiale en chinois contemporain. University Paris 7 , Ph.D. dissertation. [Published as: Lu, Peng. 2008. Les phrases complexes en chinois. Beijing: Waiwen chubanshe (www.flp.com.cn)].

LÜ Shuxiang et al. (eds.) 2000. Xiàndài hànyǔ bābáicí [Eight hundred words of Modern Mandarin]. Běijīng: Shangwu.

MunARO, Nicola \& POLLOCK, Jean-Yves. 2005. Qu'est-ce que (qu)-est-ce-que ? A case study in comparative Romance interrogative syntax. The Oxford Handbook of Comparative Syntax, ed. Guglielmo Cinque \& Richard S. Kayne, 542-606. Oxford: Oxford University Press.

Munaro, Nicola \& Poletto, Cecilia. 2006. The diachronic path towards particles in the North-Eastern dialects. Nordic Journal of Linguistics 28.2, 247-268.

NewMEYeR, Frederick J. 2005. Possible and probable languages. Oxford: Oxford University Press.

PAN, Victor Junnan. 2007. Interrogation et quantification : le rôle et la fonction des particules et des syntagmes interrogatifs en chinois mandarin. University of Nantes: Ph.D. dissertation. [Revised version published as: PAN, Victor Junnan. 2011. Interrogatives et quantification en chinois mandarin: une approche générative. Rennes: Presses Universitaires de Rennes].

PAUL, Waltraud. 1988. The syntax of verb-object phrases: Constraints and reanalysis. Paris: Editions Langages Croisés. Available at: http://crlao.ehess.fr/document.php?id=177.

PAUL, Waltraud. 2002. Sentence-internal topics in Mandarin Chinese: The case of object preposing. Language and Linguistics 3.4, 695-714.

PAUL, Waltraud. 2005. Low IP area and left periphery in Mandarin Chinese. Recherches linguistiques de Vincennes 33, 111-134.

PAUL, Waltraud. 2006. What the topic is (not) about: The case of Chinese. Ms., CRLAO, Paris.

PAUL, Waltraud. 2008. Sentence particles from a Chinese perspective. Paper presented at the Workshop Looking for particles, Department of Language Science, University of Venice, Ca' Foscari, 4 February 2008. 
PAUL, Waltraud. 2009. Consistent disharmony: sentence-final particles in Chinese. Ms., CRLAO, Paris. Available at: http://crlao.ehess.fr/document.php?id=177.

PAUL, Waltraud. 2012. Why Chinese de is not like French de: A critical analysis of the predicational approach to nominal modification. Studies in Chinese Linguistics [The Chinese University of Hong Kong] 33, 3: 183-210.

Paul, Waltraud \& WhitMan, John. 2008. Shi...de focus clefts in Mandarin Chinese. The Linguistic Review 25.3/4, 413-451.

PAUL, Waltraud \& WhitMan, John. 2010. Applicative structure and Mandarin ditransitives. Argument Structure and Syntactic Relations. A cross-linguistic perspective, ed. Maia Duguine, Susana Huidobro \& Nerea Madariaga, 261-282. Amsterdam: Benjamins.

RizzI, Luigi. 1997. The fine structure of the left periphery. Elements of Grammar, ed. Liliane Haegeman, 281-337. Dordrecht: Kluwer.

RIZZI, Luigi. 2004. Locality and left periphery. Structures and beyond. The cartography of syntactic structure, vol. 3, ed. Adriana Belletti, 104-131. Oxford: Oxford University Press.

Ross, Claudia. 1983. On the functions of Mandarin de. Journal of Chinese Linguistics 11.2, 214-246.

SoNG, Yuzhu 1981. Guanyu shijian zhuci de he laizhe [On the tense particles de and laizhe]. Zhongguo Yuwen 1981, no. 4, 271-276.

SRIDHAR, Shikaripur. 1990. Kannada. London: Routledge.

SYBESMA, Rint. 1999. The Mandarin VP. Dordrecht: Kluwer.

SyBESMA, Rint \& LI, Boya. The dissection and structural mapping of Cantonese sentence final particles. Lingua 117, 1739-1783.

TANG, Sze-Wing. 1998. Parametrization of features in syntax. University of California, Irvine: Ph.D. dissertation.

TANG, Ting-chi. 1988. Hanyu cifa jufa lunji [Studies on Chinese Morphology and Syntax], vol. 1. Taipei: Student Book Co.

TANG, Ting-chi. 1989. Hanyu cifa jufa lunji [Studies on Chinese Morphology and Syntax], vol. 2. Taipei: Student Book Co.

TENG, Shou-hsin. 1973. Negation and aspects in Chinese. Journal of Chinese Linguistics 1.1, 14-37.

TOIVONEN, Ida. 2003. Non-projecting words. Dordrecht: Kluwer.

WhITMAN, John. 2008. The classification of constituent order generalizations and diachronic explanation. Linguistic Universals and Language Change, ed. Jeff Good, 233-252. Oxford: Oxford University Press.

XIONG, Zhongrui. 2007. Shi...de de goujian fenxi [Syntactic analyses of the construction shi...de]. Zhongguo Yuwen 2007, no. 4, 321-330.

ZHU, Dexi. 1982. Yufa jiangyi [On grammar]. Beijing: Shangwu yinshuguan.

Waltraud Paul

Centre national de la recherche scientifique Centre de recherches linguistiques sur l'Asie orientale

CRLAO, EHESS

131, Bd St. Michel

75005 Paris

FRANCE

wpaul@ehess.fr 